\title{
Environmental screening of potential biomass for green biorefinery conversion
}

\author{
Corona, Andrea; Parajuli, Ranjan; Ambye-Jensen, Morten; Hauschild, Michael Zwicky; Birkved, Morten
}

Published in:

Journal of Cleaner Production

Link to article, DOI:

10.1016/j.jclepro.2018.03.316

Publication date:

2018

Document Version

Peer reviewed version

Link back to DTU Orbit

Citation (APA):

Corona, A., Parajuli, R., Ambye-Jensen, M., Hauschild, M. Z., \& Birkved, M. (2018). Environmental screening of potential biomass for green biorefinery conversion. Journal of Cleaner Production, 189, 344-357.

https://doi.org/10.1016/j.jclepro.2018.03.316

\section{General rights}

Copyright and moral rights for the publications made accessible in the public portal are retained by the authors and/or other copyright owners and it is a condition of accessing publications that users recognise and abide by the legal requirements associated with these rights.

- Users may download and print one copy of any publication from the public portal for the purpose of private study or research.

- You may not further distribute the material or use it for any profit-making activity or commercial gain

- You may freely distribute the URL identifying the publication in the public portal 


\title{
Environmental screening of potential biomass for green biorefinery conversion
}

\author{
Andrea Corona $^{1^{*}}$, Ranjan Parajuli ${ }^{2}$, Morten Ambye-Jensen $^{3}$, Michael Hauschild ${ }^{1}$, Morten Birkved $^{1}$
}

${ }_{1}$ Division for Quantitative Sustainability Assessment, Department of Management Engineering, Technical University of Denmark, Bygningstorvet, 2800 Lyngby, Denmark

${ }_{2}$ Ralph E. Martin Department of Chemical Engineering, University of Arkansas, Fayetteville, AR 72701, USA

${ }_{3}$ Department of Engineering, Aarhus University, Hangøvej 2, 8200 Aarhus, Denmark

*Corresponding author, email: corona@dtu.dk, Phone +4545251544

\section{GRAPHICAL ABSTRACT}

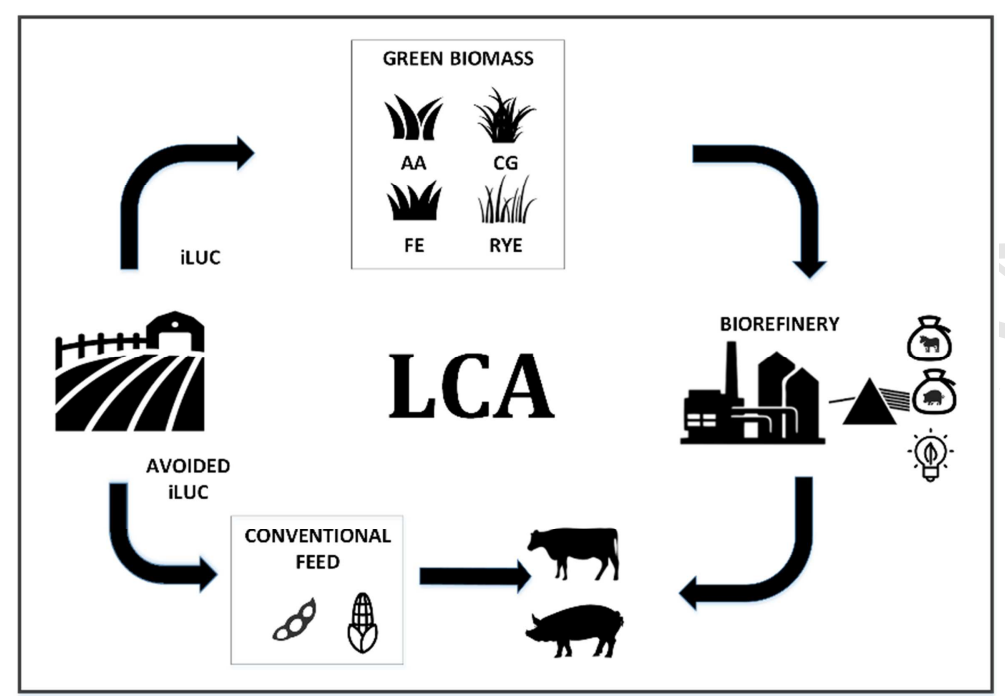

\section{ASTRACT}

Green biorefinery (GBR) is a new biorefinery technology for the conversion of fresh biomass to value added products. In the present study, we combined a Process Flowsheet Simulation (PFS) and Life Cycle Assessment (LCA) of a small scale decentralized GBR to screen environmental impact profiles for potential biomass feedstocks for GBR conversion. Furthermore, we carried out hotspot and sensitivity analysis to identify where the largest impacts arise in the biorefining stage in order to provide recommendations and focus points for GBR technology developers. The GBR considered in this study produces a protein-rich feed for monogastric animals and an energy-rich feed from the press pulp and biogas from the GBR residues. The included biomass feedstocks are: alfalfa, grass-clover, festulolium and ryegrass. These biomasses were selected to accommodate variations in central biomass characteristics like: crop yields, rate of fertilizer application, chemical biomass compositions and related potential environmental implications. Among the studied crops, alfalfa provides the best overall environmental performance due to its high yield and low agricultural input demands. Results of the hotspot analysis further identified the coagulation and the drying as the processes that induce most of the environmental impacts in the biorefining stage. Conversion of green biomass for the production of feed and energy could provide environmental benefits compared to the production of conventional feed. However, the GBR technology have still room for optimization in order to further reduce the environmental impacts, across all impact categories, by decreasing energy consumption and increasing conversion efficiency. 


\section{Introduction}

Biorefinery technology is now emerging as a means to create new ways of converting biomass to new types of renewable products (Cherubini, 2010). The resulting biobased products may have similar functionality as corresponding fossil-based products and are also expected to bring significant environmental benefits (Fiorentino and Ripa, 2016). Like the traditional oil refineries, biorefineries aim at separating the biomass into its (most) valuable components. The components obtained from biorefining are further converted by several means (e.g. biological, thermochemical, mechanical, etc.) into marketable products. This refining strategy allows for maximizing the output of the biomass conversion instead of relying only on a conversion providing one single biomass components (e.g. carbohydrates in ethanol biorefineries).

Biorefineries can be classified according to the biomass feedstock used. The major biorefinery types are: whole crop biorefineries which use cereals (e.g. mills and $1^{\text {st }}$ generation bioethanol) (Cherubini et al., 2009), lignocellulosic biorefineries which use nature "dry" materials (e.g. cellulose containing biomass, agricultural residue and waste) (Ree et al., 2014), green biorefineries which utilize nature "wet" feedstock (e.g. grasses and immature cereals) (Kamm et al., 2006) and forest-based biorefineries utilizing woody biomass (Cherubini et al., 2009).

Green biorefineries can be defined as "complex systems based on ecological technology for comprehensive (holistic), material and energy utilization of renewable resources and natural materials using green and waste biomass and focalising on sustainable regional land utilization" (Kamm and Kamm, 2007). Green biorefineries hence seek to utilize fresh, green biomasses (e.g. grasses), for production of fuel feed and chemicals (Kamm, 2013). Most of the GBR configurations fractionate herbaceous biomass (fresh or silage) in a liquid and a solid fraction. The solid fraction can be used as feed (Cong and Termansen, 2016; Hermansen et al., 2017); fermentation feedstock (Kamm et al., 2009; Leiß et al., 2010); for biogas production (Molinuevo-Salces et al., 2015; Santamaría et al., 2015); dried and used as structural material (Kromus et al., 2004; Mandl, 2010; O'Keeffe et al., 2011b) or as a solid fuel (Richter et al., 2010). The liquid fraction on the other hand, contains several valuable components (e.g. proteins, amino-acids, vitamins etc.) which can be separated from the juice by various separation techniques. Proteins are generally the targeted component due to the high concentration hereof in the liquid fraction. However, other components may also be extracted using further separation techniques. After isolation of the target component, the decanted juice can be utilized for biogas production (Kamm et al., 2016; Thomsen et al., 2004; Xiu and Shahbazi, 2015) or fermentation medium (Andersen and Kiel, 2000; Thomsen et al., 2004), minimizing the waste production.

The interest for green biorefineries has three main drivers. The primary driver is connected with the need for managing surplus grassland, as an estimate revealed that about $10-20 \%$ of 16.4 mil ha of the grassland within the European Union (EU) are regarded as being potentially available for alternative uses, besides grazing (Mandl, 2010). Secondly, the importance of GBR has been stressed in order to seek alternatives to the dry grass pellet production, in decline nowadays due to the high energy intensity (Kamm et al., 2009). The third driver is the need for developing alternative feeds, in the Danish case for the livestock sector to reduce dependency on imported livestock feed, e.g. soybean meal (Termansen et al., 2016). However, until now, large-scale commercial production of biobased products from green biorefineries is yet to be seen on the global market. Different attempts to utilize grasses in pilot scale GBRs are seen in several European countries (Bals et al., 2012; Kamm et al., 2009; Kromus et al., 2004; Mandl, 2010; O'Keeffe et al., 2011a). All these attempts have shown that processing grasses to high value products is technically possible.

For comparison of the environmental performance of biorefineries and petro-refineries, life cycle assessment (LCA) methodology has been used in many studies (Cherubini et al., 2011; Malça and Freire, 2010; Manik and Halog, 2012; Wiloso et al., 2012). These studies were mostly focused on biofuels, e.g. bioethanol or biodiesel (Cherubini and Jungmeier, 2009; Cherubini and Ulgiati, 2010; Hsu et al., 2010). Few studies covering the energetics and economic considerations related to a green biorefinery plant have been published so far (Kamm et al., 2009; Kromus et al., 2004; O'Keeffe et al., 2012, 2011b). Only three studies assessing the environmental implications related to GBR systems were identified in the literature. Cong et al. (2016) performed a bio-economic analysis of pork production investigating the utilization of the GBR feed products in the pork diet. The author looked at the environmental implication (mainly connected to nitrogen emission, energy and land use) of using one of the GBR output as pig feed. Parajuli et al. (2017a) applied LCA to look at possible synergies between the GBR and bioethanol production systems. Likewise, in another study, Parajuli et al. (2018) looked at synergies between crop and livestock systems. The study showed that when entire environmental evaluation of the mixed crop-livestock system was disected into different value chains, the contribution of the agricultural stage (i.e. the cultivation of the feedstock) on the biorefinery environmental impact profile was substantial. Furthermore, environmental footprints of different types of grasses is highly depending to the variations of the raw material inputs and the farm management practices, as reported by Parajuli et al. (2017b) and Parajuli et al. 
(2016). Likewise, the physio-chemical properties of different biomasses are one of the major driver the optimize the yield of specific biobased products and for the deciding the sustainable biorefinery conversion pathways, (Parajuli et al., 2015). Considering these biomass and farm specific properties and the importance of the cultivation stage on the overall biorefinery footprint, it was pertinent to analyse different types of feedstocks for the GBR system, as is evaluated in the current study. Yet, until the preparation of this study, an LCA capturing the essence of the biorefinery, covering all the material flows starting from the production of different potential biomasses to the delivery of biobased products, and assessing the effect of choosing feedstocks on the overall GBR environmental performance has not been conducted.

The current study evaluates the environmental impact potentials induced by converting different green biomass feedstocks in a GBR for the production of livestock feed and energy. The candidate biomasses were selected to accommodate variations in biomass characteristics like yields, rate of fertilizer application, chemical compositions and related potential environmental implications. The GBR concept assessed in this study is a small-scale decentralized biorefinery, which produces a protein concentrate from the press juice, a solid fraction used as animal energy-feed and biogas from the GBR residues. The study takes a cradle to gate perspective combining the environmental LCA results of producing the studied crops together with the results for the conversion of these feedstocks in the GBR system. Subsequently, hotspot and sensitivity analyses were performed to identify the most environmentally taxing processes in the biorefinery system.

\section{Materials and Methods}

The overall approach followed in this section is a two-step procedure describing: (i) the production of biomasses at the farm and their conversion in a green biorefinery and (ii) the LCA model. The crops selected as biomass feedstock are: grass-clover, ryegrass, alfalfa and festulolium. For the first three biomass types, the environmental impact potentials induced in relation to farming were adapted from studies by Parajuli et al. (2017b) and Parajuli et al. (2016). The methods applied to obtain the farming related impact potentials are described in the respective studies. For the fourth biomass type, a detailed description of the farming related impacts is presented in the Supporting Information (SI.2). The Process Flowsheet Simulation (PFS), describing the conversion of the studied crops in the biorefinery, was developed in Excel and is based on the results obtained from tests of the green biorefinery pilot plant carried out at the Agriculture Research Centre, in Foulum, Denmark (DCA, 2016). The PFS calculates mass transformation, inputs and outputs (in terms of auxiliary materials and energy) needed for the conversion of the selected crops in the biorefinery. Results from the PFS were also compared with other studies (Kamm et al., 2010; Kromus et al., 2004; O'Keeffe et al., 2011b). The Life Cycle Inventory (LCI) for the background processes (for the production of related material inputs, both energetic and non-energetic) is based on EcoInvent v3 (Wernet et al., 2016) while the product system modelling was performed using GaBI 6 software (PE International AG, 2012).

\subsection{Biorefinery description}

\subsubsection{Production of the biomasses and related emissions}

The selected biomass types: grass-clover, ryegrass alfalfa and festulolium are assumed grown on Danish arable land with sandy and loamy soils (NaturErhvervstyrelsen, 2015). The cultivation period for grass-clover and ryegrass is 2 years with a harvesting frequency of four times per year (Jørgensen et al., 2011). The yields for grass-clover and ryegrass (Table 1) were based on the average Danish yields (2007-2011) (Kristensen, 2015). Alfalfa was assumed grown in a 3-years rotation cycle (Jørgensen et al., 2011) with three harvests per year. The yields were based on NaturErhvervstyrelsen (2013) and Møller et al. (2005). Annual pesticides application rates for grass-clover and ryegrass were calculated from the total amount of active ingredients applied during the life cycle years of the biomass production (Ørum, 2013). For alfalfa application rates were taken from SEGES (2010). Table 1 summarizes the material inputs for the agricultural stage of the considered biomasses. Regarding festulolium, it is a novel grass hybrid of perennial ryegrass (Lolium Perenne) and a more stress-resistant grass species, Festuca Pratensis. The average annual yield of the biomass was $15 \mathrm{t} \mathrm{DM/ha}$ grown in sandy soil. For all considered biomasses, the primary energy input during the farm operations (tillage + application of agrochemicals + harvest and loadings) were calculated based on fuel inputs as suggested in Dalgaard et al., (2001) and frequencies of farm operations based on Jørgensen et al. (2011).

The synthetic fertilizers assumed to be used for the production of the biomasses were: $\mathrm{N}=$ calcium ammonium nitrate, $\mathrm{P}=$ triple superphosphate and $\mathrm{K}=$ potassium chloride. Changes in Soil Organic Carbon (SOC) were calculated from the net SOC input. The net SOC input was calculated as the difference between the organic matters available to soil from the non-harvestable residues of the reference land (cultivated with spring barley and with straw incorporated) and the organic matters available from residues of the selected crops (see SI, Table S.2). The $\mathrm{CO}_{2}$ emission reduction potential over 100 years was assumed to be $9.7 \%$ of the net SOC input (Petersen et al., 2013). Regarding the emissions at the 
farm level, the direct and indirect nitrous oxide emission $\left(\mathrm{N}_{2} \mathrm{O}-\mathrm{N}\right)$ were based on emission factors reported in IPCC (2006). Factors applied to quantify $\mathrm{NH}_{3}$ emission from $\mathrm{N}$-fertilizer were $2 \%$ of applied $\mathrm{N}$-fertilizer (EEA, 2013; Nemecek and Kägi, 2007) and from the crops $0.5 \mathrm{~kg} \mathrm{NH}_{3}-\mathrm{N}$ for grasses (Sommer et al., 2004). Denitrification estimates were obtained from the SimDen model (Vinther, 2005). For pesticide application, emission distributions factors of active ingredients to air and freshwater during the pesticide spraying at the field were calculated using the PestLCI 2.0.6 (Dijkman et al., 2012). Regarding soil quality, the SOC stock change ( $\Delta$ SOC stock) was used as indicator, as suggested in Brandão et al. (2011) and Milà i Canals et al. (2007). The calculations covered impacts related to land transformation relative to reference land use (i.e. situation where the current crop management practices/activity was not practiced).

Table 1. Input-Output of materials for the production of the selected biomasses.

\begin{tabular}{|c|c|c|c|c|c|}
\hline Input & Unit & $\begin{array}{l}\text { Grass- }^{\text {clover }^{a}}\end{array}$ & Ryegrass $^{a}$ & $\underset{a}{A l f a l f a}$ & Festulolium $^{b}$ \\
\hline Land & ha-a & 1 & 1 & 1 & 1 \\
\hline Seed & $\mathrm{kg} \mathrm{ha}^{-1}$ & 8 & 9 & 11 & 25 \\
\hline \multicolumn{6}{|l|}{ Synthetic fertilizer } \\
\hline$N$ & $\mathrm{~kg} \mathrm{ha}^{-1} \mathrm{y}^{-1}$ & 193 & 279 & 0 & 450 \\
\hline$P$ & $\mathrm{~kg} \mathrm{ha}^{-1} \mathrm{y}^{-1}$ & 33 & 32 & 33 & 87 \\
\hline K & $\mathrm{kg} \mathrm{ha}^{-1} \mathrm{y}^{-1}$ & 172 & 214 & 214 & 290 \\
\hline Lime & $\mathrm{kg} \mathrm{ha}^{-1} \mathrm{y}^{-1}$ & 84 & 84 & 56 & 24 \\
\hline Pesticides & $\mathrm{kg} \mathrm{ha}^{-1} \mathrm{y}^{-1}$ & 0.03 & 0.03 & 0.33 & 0.15 \\
\hline Lubricant $^{c}$ & $\mathrm{~L} \mathrm{ha}^{-1} \mathrm{y}^{-1}$ & 11 & 11 & 16.13 & 13.34 \\
\hline Direct primary energy input ${ }^{d}$ & MJ ha ${ }^{-1} y^{-1}$ & 3644 & 3794 & 4188 & 3462 \\
\hline
\end{tabular}

Output

Biomass yield

$\mathrm{t} \mathrm{DM} \mathrm{ha}^{-1} \mathrm{y}$

7.71

8.75

12.20

15.00

Emissions

(a) Net C sequestration ${ }^{e}$

$\mathrm{kg} \mathrm{CO}_{2}$-eq ha ${ }^{-1} \mathrm{y}^{-1} \quad-1012$

$-1283$

(b) N emissions

$\mathrm{kg} \mathrm{N} \mathrm{ha}^{-1} \mathrm{y}^{-1}$

- $\mathrm{NH}_{3}-\mathrm{N}$

4.4

6.1

0.5

9.5

- $\quad \mathrm{N}_{2} \mathrm{O}-\mathrm{N}$ emissions $($ direct + indirect)

3.62

4.41

0.6

5.24

- N-leaching

44

9

40

9

(c) P-leaching ${ }^{f}$

kg P ha ${ }^{-1} \mathrm{y}^{-1}$

1.6

1.6

1.65

4

\footnotetext{
${ }^{a}$ Adapted from (Parajuli et al., 2017b, 2016).

${ }^{b}$ Festulolium production input were based on Jorgensen, U (2016, pers. comm.) (SI, Table S.1).

${ }^{c}$ Lubrications calculated as $3.6 \mathrm{MJ} \mathrm{l}^{-1}$ diesel consumption (Dalgaard et al., 2001).

${ }^{d}$ Total diesel fuel input for the farm operations (tillage, application of agro-chemicals, sowing, harvest).
} 


\footnotetext{
${ }^{e}$ Negative values indicate soil carbon sequestration.

${ }^{f}$ Emission factors based on (Nielsen and Wenzel, 2007) (SI, Table S.3).
}

\subsubsection{Properties of biomasses in relation to the conversion in GBR}

The selection of the crops for this study was done to study diverse types of herbaceous biomass representing different level of yields, fertilizer application and agricultural management practices. Furthermore, the studied feedstock crops have a different biochemical composition, which affects the GBR conversion process and the quality of the output products. Table 2 presents a detailed biochemical composition for the selected crops. With regard to Festulolium, it was assumed similar to grass (Jørgensen, 2016).

Table 2. Biochemical composition of the selected crops.

\begin{tabular}{|c|c|c|c|c|c|}
\hline & $\begin{array}{l}\text { Biochemical } \\
\text { composition }\end{array}$ & Grass-clover & Ryegrass & Alfalfa & Festulolium $^{c}$ \\
\hline \multirow[t]{9}{*}{$\%$ of $D M$} & Protein $^{b}$ & $21.6 \%$ & $21.3 \%$ & $19.5 \%$ & $21.3 \%$ \\
\hline & Sol. Carbohydrates ${ }^{\mathrm{b}}$ & $15.0 \%$ & $12.0 \%$ & $13.0 \%$ & $12.0 \%$ \\
\hline & Hemicellulose $^{\mathrm{b}}$ & $16.7 \%$ & $23.3 \%$ & $20.0 \%$ & $23.3 \%$ \\
\hline & Cellulose $^{\mathrm{b}}$ & $18.7 \%$ & $24.3 \%$ & $23.3 \%$ & $24.3 \%$ \\
\hline & $\operatorname{Lignin}^{\mathrm{b}}$ & $9.0 \%$ & $6.1 \%$ & $8.6 \%$ & $6.1 \%$ \\
\hline & Residual $^{\mathrm{b}}$ & $9.6 \%$ & $2.0 \%$ & $5.0 \%$ & $2.0 \%$ \\
\hline & $\mathrm{P}^{\mathrm{a}}$ & $0.4 \%$ & $0.4 \%$ & $0.3 \%$ & $0.4 \%$ \\
\hline & $\mathrm{K}^{\mathrm{a}}$ & $2.9 \%$ & $3.4 \%$ & $2.7 \%$ & $3.4 \%$ \\
\hline & $\operatorname{Ash}(-\mathrm{P} \& \mathrm{~K})^{\mathrm{a}}$ & $6.1 \%$ & $7.2 \%$ & $7.6 \%$ & $7.2 \%$ \\
\hline$\%$ of total & Water $^{b}$ & $82 \%$ & $81 \%$ & $80 \%$ & $81 \%$ \\
\hline \multicolumn{6}{|c|}{${ }^{a}$ Adapted from Moller (2005). } \\
\hline \multicolumn{6}{|c|}{${ }^{b}$ Adapted from Thøgersen and Kjeldsen (2015). } \\
\hline \multicolumn{6}{|c|}{ ' Data for Festulolium based on (Jørgensen, 2016). } \\
\hline
\end{tabular}

\subsubsection{Green biorefinery system description}

The studied GBR utilizes fresh biomass for the integrated production of feed, products (such as chemicals and materials) and energy. Conversion of fresh biomass allows for separation of valuable component (e.g. protein, vitamins etc.) which are degraded during a conventional storage process. The GBR concept assessed in this study is a small-scale decentralized biorefinery, with a capacity of 20.000 ton $_{\mathrm{DM}} / \mathrm{yr}$. The studied GBR produces a protein-rich feed, from the press-juice, targeted to replace soybean meal as protein-rich fodder for monogastric animals (e.g. pork); a solid fraction used as energy-rich feed for ruminants and biogas from the GBR residues. In this way, biomass utilization is maximized, contrary to conventional grass processing facilities, such as grass pellets production, which produces only a single product used as energy-rich feed for ruminants (Kamm et al., 2016). This study utilizes the GBR concept as applied in the pilot plant test facility at the Agriculture Research Centre, Foulum, Denmark. Conversion and separation efficiencies at each conversion step were provided for each biochemical component. From those data, a PFS representing the GBR system was developed to calculate conversion efficiencies, energy consumption and amounts and quality of produced biobased products. 
The GBR processes represent a sequence of five main steps:

i. Maceration: the fresh biomass is pre-treated to reduce the material size for the following fractionation step. The biomass is cut in small pieces, down to $10 \mathrm{~mm}$. Energy consumption for the maceration process is sourced from (Hjorth et al., 2011) and adapted for each specific crop.

ii. Fractionation: the macerated biomass is fed to a screw press for the fractionation process. The screw press separates the biomass into the juice utilized for the protein production, and the solid fraction. The solid fraction (or press-pulp) contains valuable elements and is utilized as a feed for ruminants. Utilization as feed allows for exploiting that part of the carbohydrate content of the biomass which is not solubilized in the juice. Electricity consumption for the fractionation process is calculated based on the trials performed at the full-scale pressing process at Ribe Grønttørreri (Ambye-Jensen, 2017) and adapted for the tested biomasses, depending on their water content. The press pulp is dried to DM95 and used as energy-feed for ruminants.

Calculation of the substitution factor of conventional feed was based on the digestible energy (dE) content of the feed. The calculation of the feed energy content is consistent with the methodology used in EcoInvent and described in (IPCC, 2006). Digestibility of the solid feed was assumed to be 65\% (Hermansen et al., 2017). The product was assumed to enter the energy-feed market, hence the substituted product in this case was selected to be the "Market for energy feed" (Weidema et al., 2013).

Table 3. Biochemical composition, feeding value and substitution factor of the solid fraction.

\begin{tabular}{llllll}
\hline Solid fraction after the pressing process & Grass-clover & Ryegrass & Alfalfa & Festulolium \\
\hline \% of DM & Protein & $17.8 \%$ & $16.5 \%$ & $15.3 \%$ & $16.5 \%$ \\
& Sol. carbohydrates & $6.7 \%$ & $5.1 \%$ & $5.5 \%$ & $5.1 \%$ \\
& Hemicellulose & $21.2 \%$ & $27.9 \%$ & $24.2 \%$ & $27.9 \%$ \\
& Cellulose & $27.1 \%$ & $33.3 \%$ & $32.2 \%$ & $3.3 \%$ \\
& Lignin & $13.3 \%$ & $8.5 \%$ & $12.1 \%$ & $1.4 \%$ \\
& Residual & $7.2 \%$ & $1.4 \%$ & $3.6 \%$ & $0.3 \%$ \\
& P & $0.3 \%$ & $0.3 \%$ & $0.2 \%$ & $1.9 \%$ \\
& K & $1.7 \%$ & $1.9 \%$ & $1.5 \%$ & $5.1 \%$ \\
\hline Ash (-P\&K) & $4.6 \%$ & $5.1 \%$ & $5.4 \%$ & $64.3 \%$ \\
\hline Feed properties & Water & $67.2 \%$ & $64.3 \%$ & $62.3 \%$ & 11.53 \\
\hline
\end{tabular}

iii. Coagulation: the temperature of the juice is raised to $80^{\circ} \mathrm{C}$ to allow the protein coagulation. Heat demand was estimated based on the juice calorific value and flowrate. Electricity consumption for this process (pumps and agitators) was adapted from (Kamm et al., 2009).

iv. Separation: a centrifuge separates the coagulated protein from the liquid residue. After centrifugation, the protein concentrate has a DM of approximately $36 \%$. The liquid residue after separation, still contains valuable elements (see Table 4) and is sent to a digester for biogas production.

The amount of biogas produced by the stillage fraction in a biogas plant was estimated using the Buswell formula (Buswell and Mueller, 1952), assuming a biogas conversion efficiency of $70 \%$, in a hypothetical 2stage "wet" mesophilic anaerobic digestion plant (Hamelin et al., 2014). The biogas produced is supplied to a CHP with an electrical efficiency of $\eta=40 \%$ and thermal efficiency of $\eta=45 \%$ (O'Keeffe et al., 2011b). The digestate was assumed to be subsequently spread on the field within the catchment area supplying the GBR, hence avoiding the production of conventional fertilizers (O'Keeffe et al., 2011a). Calculation of the fertilizer potential of the digestate was taken from (O'Keeffe et al., 2011b) and adapted to the selected biomass. Table 4 presents the biochemical composition, methane potential and biogas yield of the liquid residue. 
Table 4. Biochemical composition and methane potential of the liquid residue after protein removal. Biogas yield is calculated for 1 ton $_{D M}$ of biomass input.

\begin{tabular}{|c|c|c|c|c|c|}
\hline \multicolumn{2}{|c|}{ Composition liquid residue } & \multirow{2}{*}{$\begin{array}{c}\text { Grass-clover } \\
6.7 \%\end{array}$} & \multirow{2}{*}{$\begin{array}{c}\text { Ryegrass } \\
7.9 \%\end{array}$} & \multirow{2}{*}{$\begin{array}{c}\text { Alfalfa } \\
6.9 \%\end{array}$} & \multirow{2}{*}{$\begin{array}{c}\text { Festulolium } \\
7.9 \%\end{array}$} \\
\hline \% of $D M$ & Protein & & & & \\
\hline & Sol. carbohydrates & $50.5 \%$ & $48.6 \%$ & $50.2 \%$ & $48.6 \%$ \\
\hline & Hemicellulose & $8.6 \%$ & $14.4 \%$ & $11.8 \%$ & $14.4 \%$ \\
\hline & Cellulose & $0.4 \%$ & $0.6 \%$ & $0.6 \%$ & $0.6 \%$ \\
\hline & Lignin & $0.1 \%$ & $0.1 \%$ & $0.1 \%$ & $0.1 \%$ \\
\hline & Residual & $16.5 \%$ & $4.1 \%$ & $9.9 \%$ & $4.1 \%$ \\
\hline & $\mathrm{P}$ & $0.8 \%$ & $1.0 \%$ & $0.7 \%$ & $1.0 \%$ \\
\hline & $\mathrm{K}$ & $10.2 \%$ & $14.3 \%$ & $10.9 \%$ & $14.3 \%$ \\
\hline & Ash (-P\&K) & $6.3 \%$ & $8.9 \%$ & $9.0 \%$ & $8.9 \%$ \\
\hline$\%$ of total & Water & $95.2 \%$ & $95.7 \%$ & $95.1 \%$ & $95.7 \%$ \\
\hline \multirow[t]{2}{*}{$\begin{array}{l}\text { Biogas } \\
\text { Properties }\end{array}$} & $\begin{array}{l}\text { Methane potential } \\
{\left[\mathrm{m}^{3} \mathrm{CH}_{4} / \mathrm{ton}_{\mathrm{DM}}\right]}\end{array}$ & 0.280 & 0.304 & 0.295 & 0.304 \\
\hline & Methane yield $\mathrm{m}^{3}$ & 13.47 & 12.13 & 12.33 & 12.13 \\
\hline
\end{tabular}

$v$. Drying: The coagulated protein is subsequently dried to DM95. The drying process uses natural gas to produce heat. It was assumed that $50 \%$ of the heat from drying can be recycled to the coagulation process. The drying process makes the feed more appealing for the users compared to a wet feed, improving its durability as well as transportation and logistics cost (DCA, 2016). Alternatively, the coagulated protein can also be used directly on-site in a wet-feeding system without drying.

Table 5. Biochemical composition, protein content and substitution factor for the protein concentrate.

\begin{tabular}{llllll}
\hline Composition of the protein concentrate & Grass-clover & Ryegrass & Alfalfa & Festulolium \\
\% of DM & Protein & $47.0 \%$ & $50.7 \%$ & $46.3 \%$ & $50.7 \%$ \\
& Sol. Carbohydrates & $16.9 \%$ & $14.8 \%$ & $16.0 \%$ & $14.8 \%$ \\
& Hemicellulose & $6.7 \%$ & $10.3 \%$ & $8.8 \%$ & $10.3 \%$ \\
& Cellulose & $2.7 \%$ & $3.9 \%$ & $3.7 \%$ & $3.9 \%$ \\
& Lignin & $0.4 \%$ & $0.3 \%$ & $0.5 \%$ & $0.3 \%$ \\
& Residual & $12.9 \%$ & $2.9 \%$ & $7.3 \%$ & $2.9 \%$ \\
& P & $0.4 \%$ & $0.5 \%$ & $0.3 \%$ & $0.5 \%$ \\
& $\mathrm{~K}$ & $1.4 \%$ & $1.8 \%$ & $1.4 \%$ & $1.8 \%$ \\
\hline Ash (-P of total & Water & $11.5 \%$ & $14.8 \%$ & $15.6 \%$ & $14.8 \%$ \\
\hline
\end{tabular}




\begin{tabular}{llllll}
\hline $\begin{array}{l}\text { Feed } \\
\text { properties }\end{array}$ & $\mathrm{CP}\left[\mathrm{kg} / \mathrm{kg}_{\mathrm{DM}}\right]$ & 0.41 & 0.44 & 0.40 & 0.44 \\
& Substitution factor[-] $^{*}$ & 0.96 & 1.04 & 0.95 & 1.04 \\
\hline
\end{tabular}

The protein concentrate has a protein content of approximately $46-50 \%_{\mathrm{w}} \mathrm{DM}$, can be used as feed for monogastric animals (e.g. pigs) in substitution of other protein-rich feed, such as soybean meal (Kragbæk, 2014) which has similar composition and protein content. The substitution factor for soymeal was based on the digestible protein content in line with the EcoInvent methodology. The substitution factor was calculated assuming the digestibility of the protein concentrate of $85 \%$ (Hermansen et al., 2017). The substituted process in this case was Market for soybean meal (Weidema et al., 2013)

Table 6 shows an overview of the GBR process, the amount of products and the energy consumption within the system for the different crops. The inventory is specific for the conversion of 1 ton $_{\mathrm{DM}}$ of biomass. Figure 1 presents a graphical representation of the biorefinery (with ryegrass as feedstock biomass), as Sankey diagram, identifying the fate of each biochemical component in the biorefinery conversion pathway and where it ends up in the intermediate and final GBR products.

Table 6. Output product and energy input of the GBR for the studied crops for the conversion of 1 ton $_{D M}$.

\begin{tabular}{lccccc}
\hline Crop & \multicolumn{3}{c}{ Output } & \multicolumn{2}{c}{ Energy input } \\
& $\begin{array}{c}\text { Protein Concentrate } \\
\left(\mathrm{kg}_{D M}\right)\end{array}$ & $\begin{array}{c}\text { Ruminantfeed } \\
\left(\mathrm{kg}_{D M}\right)\end{array}$ & $\begin{array}{c}\text { Biogas } \\
\mathrm{m}^{3}\end{array}$ & $\begin{array}{c}\text { Heat } \\
(\mathrm{MJ})\end{array}$ & $\begin{array}{c}\text { Electricity } \\
(\mathrm{kWh})\end{array}$ \\
\hline Grass-clover & $1.86 * 10^{2}$ & $6.68 * 10^{2}$ & 9.15 & $1.39 * 10^{3}$ & $7.33^{*} 10^{1}$ \\
Ryegrass & $1.7 * 10^{2}$ & $7.09 * 10^{2}$ & $1.21 * 10^{1}$ & $1.29 * 10^{3}$ & $7.04 * 10^{1}$ \\
Alfalfa & $1.71 * 10^{2}$ & $7.03 * 10^{2}$ & $1.24 * 10^{1}$ & $1.19 * 10^{3}$ & $6.72 * 10^{1}$ \\
Festulolium & $1.7 * 10^{2}$ & $7.09 * 10^{2}$ & $1.21 * 10^{1}$ & $1.29 * 10^{3}$ & $7.04 * 10^{1}$ \\
\hline
\end{tabular}

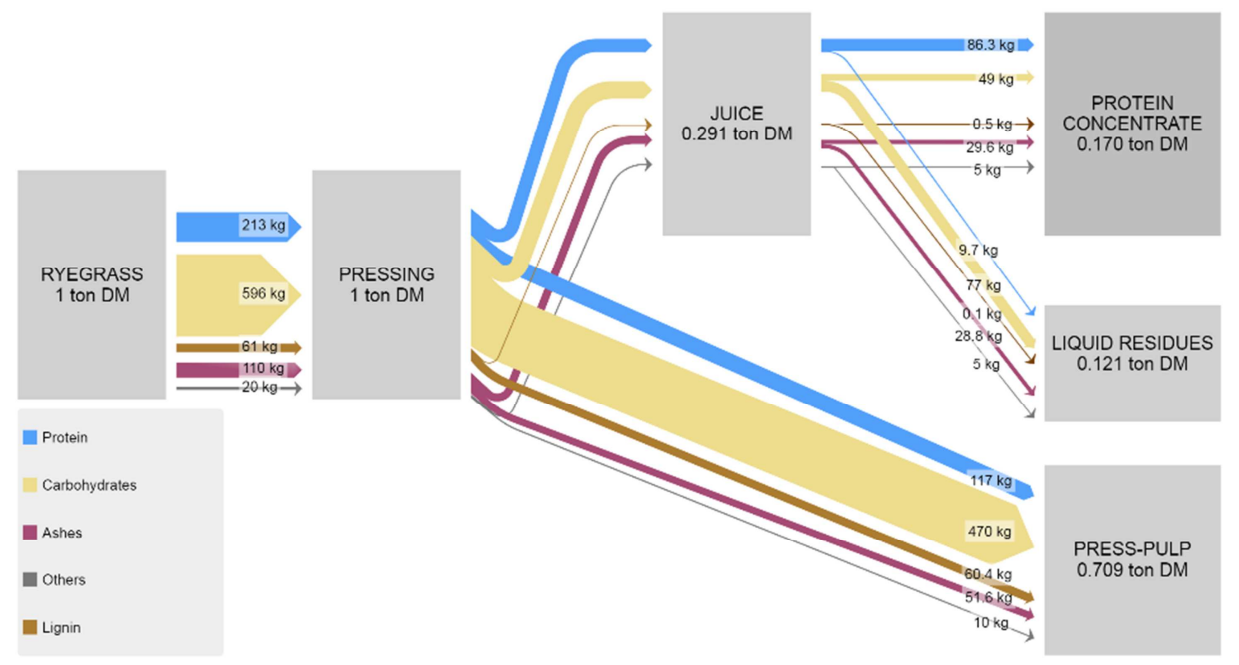

Figure 1. Sankey diagram of the GBR showing how the biochemical components of the feedstock biomass are separated into the intermediate and final products. The figure illustrates the ryegrass scenario. The other feedstocks scenario are reported in the SI.3. 


\subsection{LCA model description}

\subsubsection{Goal and Scope definition}

This study aims at comparing, at the early stage of a biorefinery design, suitable crops for GBR conversion. The studied GBR produces a protein-rich feed for monogastric animals, energy-rich feed for ruminants and biogas. Each biomass type was handled separately for the PFS. The PFS estimated the Life Cycle Inventory (LCI) related to the biorefining stage by calculating product yields and quality, material and energy consumptions from the biochemical composition of the biomasses. The system boundaries cover the entire value chain from biomass production over conversion until the biorefinery gate (Figure 2). The system boundaries were also expanded in order to include crediting of the substitution of conventional products by the GBR products.

This study attempts to answer the research question: "What is the most suitable crop for GBR conversion?" The LCA perspective must be adapted to answer this specific question, especially regarding the functional unit definition (Ahlgren et al., 2013). The functional unit selected in this study to answer the research question was "Conversion of 1tonDM of green biomass in the GBR".

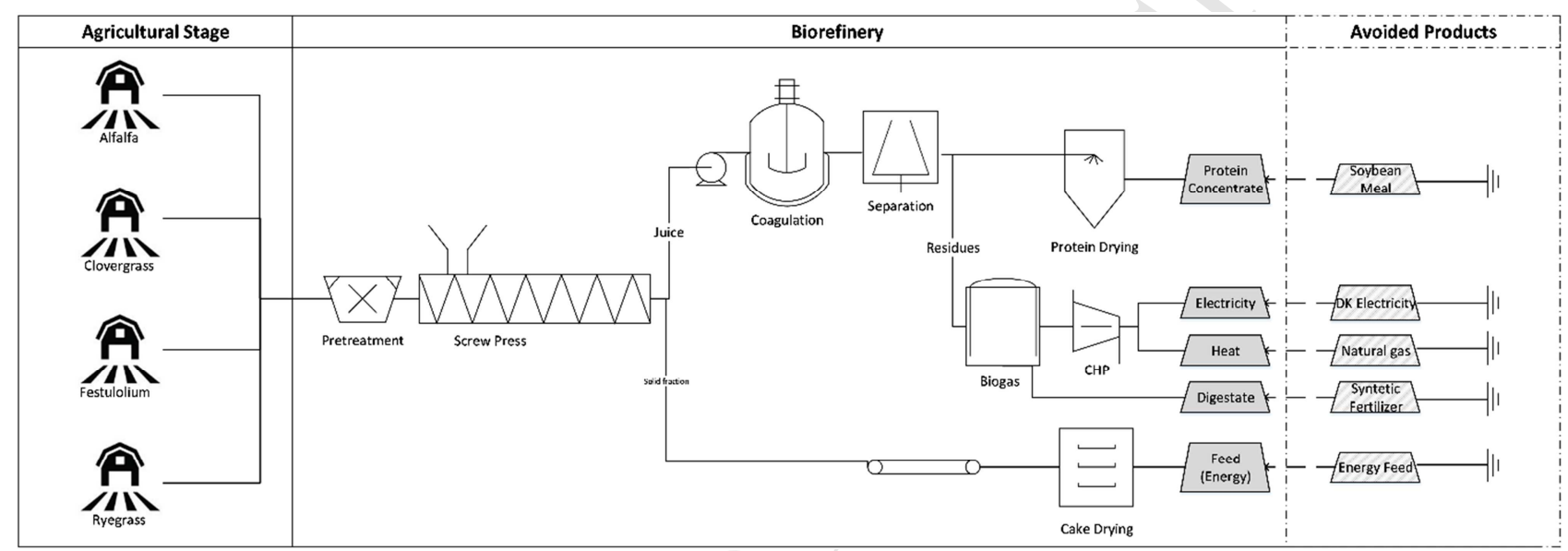

Figure 2. System boundaries of the LCA study. The system boundaries includes biomass cultivation, biorefinery conversion and the avoided conventional products (in white grey) displaced by the GBR products (in dark grey). The biorefinery section shows the most important steps involved in the conversion process.

\subsubsection{Environmental impact categories and the LCA methods}

The environmental impact scores calculated in this study are: Global Warming Potential $\left(\mathrm{GWP}_{100}\right)$, Eutrophication Potential (EP), Non-Renewable Energy (NRE) use, Agricultural Land Occupation (ALO), and Potential Freshwater Ecotoxicity (PFWTox). The selection of the environmental impact categories considered in this study was based on Parajuli et al. (2015) and aims to cover other environmental problems than only considering climate change. The "EPD" method (Environdec, 2015) was used in the assessment of the first three impact categories. Agricultural land occupation was assessed using the ReCiPe method (Huijbregts et al., 2015). The PFWTox impacts was calculated using the ILCD method (JRC, 2011) The PFWTox was calculated by covering the emissions of the foreground and background processes and the direct emissions from the pesticide application to the field. Emissions related to the application of pesticides were modelled using PestLCI 2.0.6 for the emission distribution factors (Dijkman et al., 2012) and PFWTox results calculated using the USEtox 2.0 model for the characterization factors (Fantke et al., 2015). GWP (100 also include the contributions from indirect land use changes (ILUC) induced by the occupation of arable land for the production of the green biomasses and those avoided by the credited co-products. The relevant ILUC factor was taken from Schmidt et al. (2015).

\subsubsection{Sensitivity and scenario analysis}

Sensitivity analysis was used to test the robustness of LCA results by identifying the most influencing parameters in the product system model. Results of the sensitivity analysis can be used for data refining and/or for identification of possible optimization strategies for further reduction of the environmental burdens. The sensitivity analysis examines 
the variation of the assessment results caused by variation of selected parameters in the product system model. In the present study, following parameters were selected for the sensitivity analysis to account the variations in:

- Product yields and quality

- Conversion efficiencies

- Energy consumption in the GBR

Table 7 gives an overview of the parameters tested in the sensitivity analysis. The sensitivity analysis was performed on the impact scores GWP and NRE since the GBR induces relevant contributions to these impact categories (ICs). For the other ICs, the GBR has no direct contribution. However, it has an indirect effect by the conversion efficiency (i.e. the biomass to products ratio), which influence the magnitude of the other life cycle step included in the study (agricultural stage and avoided products). For the sensitivity analysis, each parameter was individually varied by $+/-10 \%$ to see how parameter changes affected the assessment results. Results of the sensitivity analysis are presented as sensitivity ratios (SR):

Equation 1. SR: $\frac{\Delta \text { assessment result }}{\Delta \text { parameter variation }}$

Table 7. Overview of the model parameter tested in the sensitivity analysis.

\begin{tabular}{lll}
\hline Parameter name & Group & Description \\
\hline SF_protein & Product quality and yield & Substitution factor for protein \\
SF_cake & Product quality and yield & Substitution factor for cake for energy feed \\
SF_biogas & Product quality and yield & Methane yield from GBR residues \\
\%prot_to_juice & Conversion efficiencies & Protein extraction efficiency in the pressing stage \\
\%prot_sep & Conversion efficiencies & Protein separation efficiency centrifugation \\
\%heat_recy & Heat consumption & \% of heat recycled from drying to coagulation stage \\
heat_coag & Heat consumption & Heat consumption coagulation process \\
heat_dry & Heat consumption & Heat consumption drying (cake and protein) \\
el_centr & Electricity consumption & Electricity for centrifugation \\
el_coagu & Electricity consumption & Electricity for coagulation \\
el_press & Electricity consumption & Electricity for pressing \\
el_pt & Electricity consumption & Electricity for pretreatment \\
\hline
\end{tabular}

Scenario analysis was used to examine how the assessment results are influenced by the use of different energy sources for the GBR (Esen and Yuksel, 2013). Two scenarios examined different heat sources that can be used to replace natural gas (biogas and woodchips); while two additional scenarios forecasted the assessment results in 2035 and 2050 by using forecast electricity mixes for Denmark. An overview of the examined scenarios is presented in Table 8 .

Table 8. Overview of the scenario tested in the scenario analysis showing names and sources of heat and electricity for each of them.

\begin{tabular}{lll}
\hline Scenario name & Heat source & Electricity source \\
\hline$G B R \_A H B$ & Biogas $^{1}$ & Current Danish grid mix
\end{tabular}




$\begin{array}{lll}G B R \_A H W & \text { Wood-chips }^{2} & \text { Current Danish grid mix } \\ G B R \_2035 & \text { Natural Gas } & \text { Danish grid mix } 2035^{3} \\ G B R \_2050 & \text { Natural Gas } & \text { Danish grid mix } 2050^{3}\end{array}$

\footnotetext{
'From EcoInvent process: Heat, central or small-scale, other than natural gas $\{\mathrm{DK}\} \mid$ heat and power co-generation, biogas, gas engine.

${ }^{2}$ From EcoInvent process: Heat, district or industrial, other than natural gas $\{\mathrm{DK}\} \mid$ heat and power co-generation, wood chips, $6667 \mathrm{~kW}$, state-of-the-art 2014.

${ }^{3}$ Forecast energy mixes are adapted from (Sohn et al., 2017).
}

\section{Results and discussion}

\subsection{Environmental impact potentials of the biomass conversion}

Table 9 summarizes the environmental impact potentials for the production and conversion of the selected biomass feedstocks. Impact potentials are calculated for the FU: "Production and conversion of 1 ton DM $_{\text {of green biomass }}$ feedstock in the GBR". The results present the contribution of the agricultural stage and the industrial stage to the total impact score for each feedstock.

Table 9. Life Cycle Impact Assessment (LCIA) results for the production and conversion of 1ton DM $_{\text {of biomass in the }}$ GBR. The impact scores are presented as impact arising from the agricultural and the conversion stage and the total score.

\begin{tabular}{|c|c|c|c|c|c|}
\hline Impact Potentials & Units & Alfalfa & Grass-clover & Festulolium & Ryegrass \\
\hline \multicolumn{6}{|c|}{ Agricultural Stage } \\
\hline$G W P_{100}$ & $\mathrm{~kg} \mathrm{CO}_{2}$ eq/ton & $2.09 * 10^{2}$ & $5.78 * 10^{2}$ & $4.04 * 10^{2}$ & $5.97 * 10^{2}$ \\
\hline$E P$ & $\mathrm{~kg} \mathrm{PO}_{4}{ }^{3-} \mathrm{eq} / \mathrm{ton}$ & 1.26 & 2.04 & 1.68 & 1.71 \\
\hline PFWTox_total & $\mathrm{CTU}_{\mathrm{e}} /$ ton & $7.09 * 10^{1}$ & $7.9^{*} 10^{1}$ & $3.5 * 10^{2}$ & $7.44 * 10^{1}$ \\
\hline NRE, fossil & $\mathrm{MJ}$ eq/ton & $1.99 * 10^{3}$ & $2.40 * 10^{3}$ & $3.38 * 10^{3}$ & $2.86 * 10^{3}$ \\
\hline$A L O$ & $\mathrm{~m}^{2} . \mathrm{a} /$ ton & $8.52 * 10^{2}$ & $1.31 * 10^{3}$ & $6.82 * 10^{2}$ & $1.14 * 10^{3}$ \\
\hline \multicolumn{6}{|c|}{ Biorefinery Stage } \\
\hline$G W P_{100}$ & $\mathrm{~kg} \mathrm{CO} 2 \mathrm{eq} / \mathrm{ton}$ & $-6.58 * 10^{2}$ & $-6.70 * 10^{2}$ & $-6.91 * 10^{2}$ & $-6.91 * 10^{2}$ \\
\hline$E P$ & $\mathrm{~kg} \mathrm{PO}_{4}{ }^{3-} \mathrm{eq} / \mathrm{ton}$ & -1.85 & -1.9 & -1.95 & -1.95 \\
\hline PFWTox_total & $\mathrm{CTU}_{\mathrm{e}} /$ ton & $-3.6 * 10^{3}$ & $-3.8 * 10^{3}$ & $-3.86 * 10^{3}$ & $-3.86 * 10^{3}$ \\
\hline NRE, fossil & MJ eq/ton & $-1.31 * 10^{3}$ & $-1.11 * 10^{3}$ & $-1.31 * 10^{3}$ & $-1.31 * 10^{3}$ \\
\hline$A L O$ & $\mathrm{~m}^{2} . \mathrm{a} /$ ton & $-6.93 * 10^{2}$ & $-7.19 * 10^{2}$ & $-7.33 * 10^{2}$ & $-7.33 * 10^{2}$ \\
\hline \multicolumn{6}{|c|}{ Total } \\
\hline$G W P_{100}$ & $\mathrm{~kg} \mathrm{CO}_{2}$ eq/ton & $-4.49 * 10^{2}$ & $-9.16^{*} 10^{1}$ & $-2.87 * 10^{2}$ & $-9.41 * 10^{1}$ \\
\hline$E P$ & $\mathrm{~kg} \mathrm{PO}_{4}{ }^{3-} \mathrm{eq} / \mathrm{ton}$ & $-5.94 * 10^{-1}$ & $1.35 * 10^{-1}$ & $-2.68 * 10^{-1}$ & $-2.34 * 10^{-1}$ \\
\hline
\end{tabular}




$\begin{array}{llllll}\text { PFWTox_total } & \mathrm{CTU}_{\mathrm{e}} / \text { ton } & -3.53 * 10^{3} & -3.75^{*} 10^{3} & -3.51 * 10^{3} & -3.79 * 10^{3} \\ \text { NRE, fossil } & \mathrm{MJ} \text { eq/ton } & 6.79 * 10^{2} & 1.29 * 10^{3} & 2.07 * 10^{3} & 1.55^{*} 10^{3} \\ A L O & \mathrm{~m}^{2} . \mathrm{a} / \mathrm{ton} & 1.59 * 10^{2} & 5.92 * 10^{2} & -5.07 * 10^{1} & 4.1 * 10^{2}\end{array}$

The total results in Table 9 show that grass-clover induces more impacts compared to the other crops in terms of EP, GWP and ALO. Alfalfa has the best overall performance in terms of GWP, EP, and NRE. This is connected to the lower fertilization rate and high yield of this crop. Festulolium is associated with the lowest impacts in terms of ALO since this crop has the highest yield among the studied. However, the higher yield is obtained by higher fertilization rates and agricultural input, affecting NRE where Festulolium induces the highest impacts. Most of the ICs have a negative total score, since the avoided production of conventional protein-feed, energy-feed and energy, replaced by the GBR products, are associated with larger impacts than those induced by the agricultural and GBR conversion stage. For NRE all the crops have a positive score, which is connected to the agricultural inputs and the energy consumption in the biorefining process. The ALO score is negative for festulolium because of its high yield; the other crops, on the other hand, exhibit positive total ALO impacts since the land needed is larger compared to conventional crops replaced by the GBR products.

\subsubsection{Climate Change}

The assessment results reveal that the total $\mathrm{GWP}_{100}$ in all four scenario is negative. Figure 3 shows that the credits related to the avoided products have a larger contribution compared to those induced by agricultural stage and GBR process. The total impact potentials range from $-448.83 \mathrm{kgCO}_{2}$ eq/ton $\mathrm{DM}_{\mathrm{D}}$ for alfalfa to $-91.64 \mathrm{kgCO} \mathrm{C}_{2}$ eq/ton $\mathrm{DM}_{\mathrm{DM}}$ for grassclover. The induced impacts are mostly influenced by the emissions at the farm level. The agricultural stage contribution ranges from $62 \%$ (alfalfa) to $81 \%$ (ryegrass) of the total induced emission for climate change. In the agricultural stage, the largest contribution is related to $\mathrm{N}_{2} \mathrm{O}$ emissions from the field, related to the use of fertilizers. This contribution ranges from $41 \%-62 \%$ of the total agricultural impacts. The lower range is representative for alfalfa, as the crop is an N-fixing plant, application of N-synthetic fertilizer was null (SEGES, 2010). It should be noted that the GHG emissions are substantially mitigated by the SOC stock changes. SOC stock changes range from $-36 \%$ to $-76 \%$ of the $\mathrm{GWP}_{100}$ calculated at the farm level. The amount of non-harvestable residues is the major factor behind the variations. Regarding the biorefining stage, its contribution to the total induced impacts range from $19 \%$ for ryegrass to $38 \%$ for alfalfa. The difference in GWP results at the biorefinery stage is mainly connected to the different dry matter contents of the feedstocks (which is affecting the energy consumption throughout the system) and protein and carbohydrate content (which instead affects quantity and the quality -i.e. the substitution factor- of the GBR products). The credits related to the GBR products range from $-830 \mathrm{kgCO}_{2}$ eq/ton $\mathrm{DM}_{\mathrm{DM}}$ for ryegrass and festulolium to $-786 \mathrm{kgCO} 2$

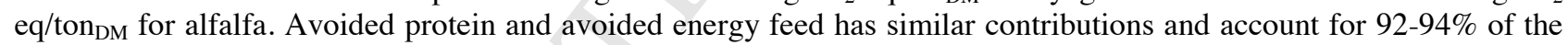
total avoided impacts in this IC. Avoided ILUC contributed to $33 \%$ of the credited impacts.

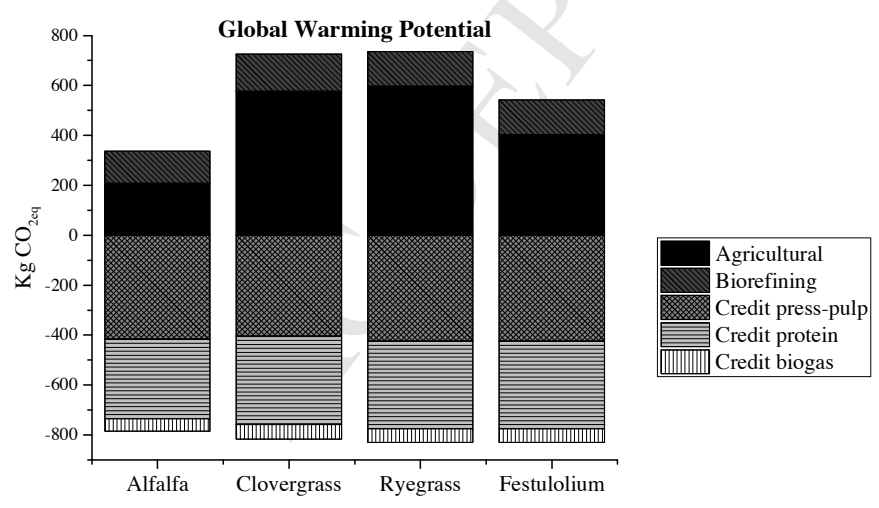

Figure 3. Midpoint results for Global Warming Potential. For each feedstock, the figure shows the total impact potential, the contribution of each life cycle stage and the credits obtained for the GBR products. 


\subsubsection{Eutrophication potential}

Regarding the eutrophication potential, three of the four feedstock scenarios have a negative total score, indicating a potential improvement in this IC for GBR compared to the conventional agricultural production (see Figure 4). Only for grass-clover, the total score is positive, due to the lower yield. The agricultural stage dominates this impact category, accounting for $96-97 \%$ of the total induced impacts. At the farm level, field emissions accounts for $47 \%-73 \%$ of the total impact potential. The lowest score is for alfalfa having no $\mathrm{N}$-fertilizer input. Regarding the credits caused by the GBR products they range from $-1.90 \mathrm{kgPO}_{4}{ }^{3-} \mathrm{eq} / \mathrm{ton}_{\mathrm{DM}}$ for alfalfa to $-2.00 \mathrm{kgPO}_{4}{ }^{3-}$ eq/ton ${ }_{\mathrm{DM}}$ for ryegrass and festulolium. The credits from the energy-feed have higher contributions to EP, ranging from 56\% to 59\% compared to those related to the protein-feed, which ranges from $37 \%$ to $39 \%$ of the total avoided impacts. Credits from the production of biogas are negligible in this IC.

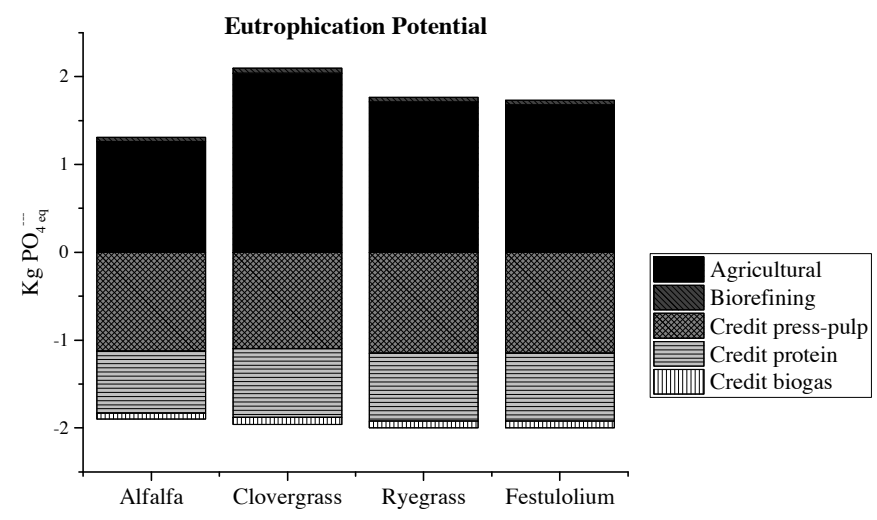

Figure 4. Midpoint results for Eutrophication potential. For each feedstock, the figure shows the total score, the contribution of each life cycle stage and the credits related to the GBR products.

\subsubsection{Freshwater Ecotoxicity impact potential}

Figure 5 shows that for potential freshwater ecotoxicity all scenarios exhibit a negative score. The credits related to the avoided impacts dominate the overall score and are 2-3 orders of magnitude higher than the induced impacts from the agricultural and GBR step. There are two reasons for this: the grass biomasses used in the biorefinery have lower pesticide application rates compared to highly industrialized crops like soy and corn/maize. The second reason resides in the inventory modelling approach used for the pesticide emissions. For the biomass converted in the GBR (i.e. the induced impacts), PFWTox is modelled using PestLCI to quantify the pesticide emissions at the field level. In contrast, for the crops related to the avoided products (e.g. soy, maize etc.) the modelling approach is based on the EcoInvent guidelines (i.e. assuming that all pesticides applied to the field is $(100 \%)$ emitted to agricultural soil). Furthermore, it is not possible to apply the PestLCI model to the avoided EcoInvent processes since the avoided crops are grown outside Europe and the pesticide model cannot yet assess other geographical regions than Europe. The reason behind the higher freshwater ecotoxicity impact potential obtained for Festulolium at farm level is connected to the crop irrigation, since irrigation was assumed necessary only for this specific crop. Hence, freshwater ecotoxicity related to electricity production was included and increased the impact potential of the agricultural stage.

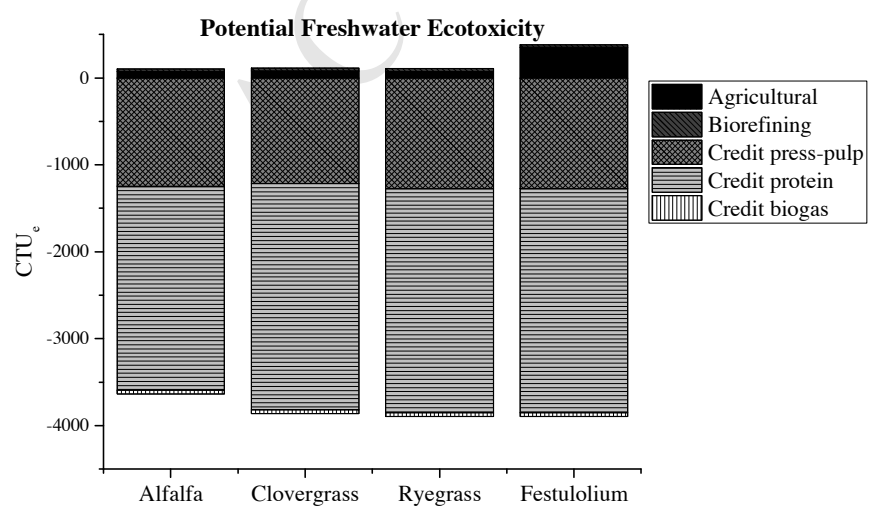


Figure 5. Midpoint results for Freshwater Ecotoxicity. For each feedstock, the figure shows the total impact potentials, the contribution of each life cycle step and the credits due to the GBR products.

\subsubsection{Non-renewable energy use}

For NRE all scenarios show a total positive score. Impact potential results range from $679 \mathrm{MJ}_{\mathrm{eq}} / \mathrm{ton}_{\mathrm{DM}}$ for alfalfa to $2070 \mathrm{MJ}$ eq/ton $\mathrm{DM}$ for Festulolium. The GBR stage accounts for $37 \%$ to $47 \%$ of the total induced impacts. Contrary to other ICs, the GBR stage has a considerable contribution to the NRE IC. The magnitude of the contribution is connected to the fact that energy utilization in the process is not yet optimized. Furthermore, the heat source assumed in this study is Natural Gas. Natural gas compared to other heat sources has a high CF in this IC $\left(38.3 \mathrm{MJ} \mathrm{eq} / \mathrm{m}^{3}\right)$.

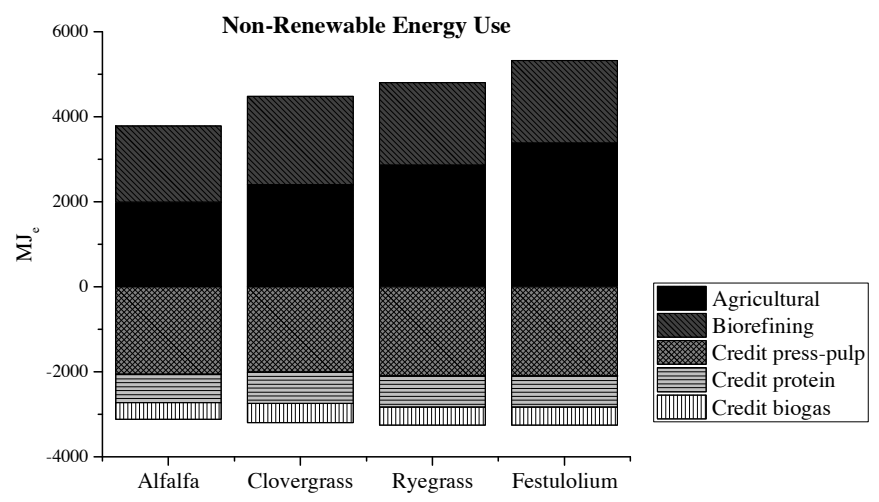

Figure 6. Midpoint results for Non-Renewable Energy Use. For each feedstock, the figure shows the total score, the contribution of each life cycle step and the credits due to the GBR products.

\subsubsection{Agricultural land occupation}

For ALO, results range from $-50 \mathrm{~m}^{2} \mathrm{a} / \mathrm{ton}_{\mathrm{DM}}$ for festulolium to $592 \mathrm{~m}^{2} \mathrm{a} / \mathrm{ton}_{\mathrm{DM}}$ for grass-clover. The induced impacts are dominated by the agricultural stage accounting for 97 to $98 \%$ of the total induced impacts. The trend found in this IC is similar to results for the Eutrophication IC. Induced ALO impacts are mainly connected with the biomass yield. Festulolium shows the lowest ALO impact potential due to its high yield of $15 \operatorname{ton}_{\mathrm{DM}} / \mathrm{ha}$; while grass-clover shows the highest impact since it has the lowest yield ( $\left.7.71 \mathrm{ton}_{\mathrm{DM}} / \mathrm{he}\right)$ among the studied crops. From the ALO results presented in figure 7, it is observable that the avoided impacts are lower than those induced by agricultural and GBR conversion, hence the overall result within the ALO IC is positive. Credits from pulp and protein have similar contribution.

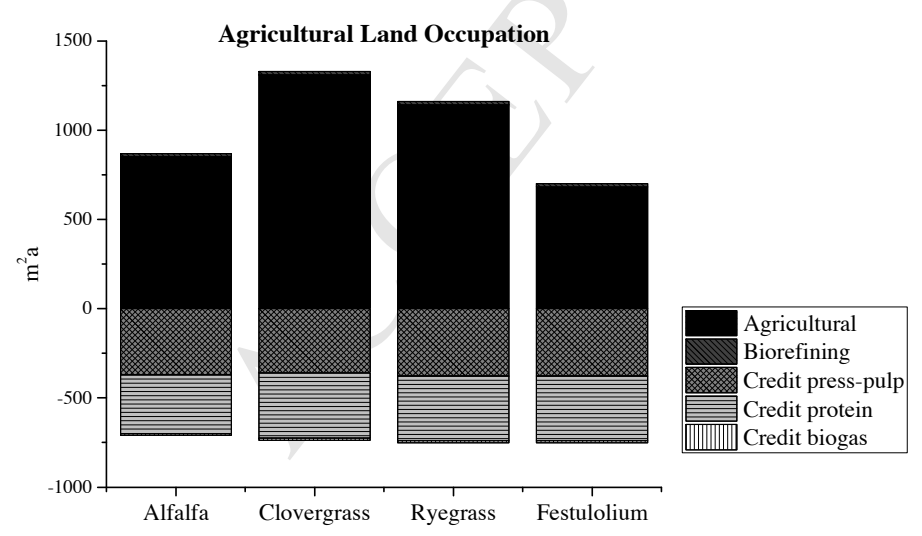

Figure 7. Midpoint results for Non-renewable Energy Use. For each feedstock, the figure shows the total score, the contribution of each life cycle step and the credits due to the GBR products. 


\subsection{Environmental focus points}

Figure 8 shows the impact potential contributions from the different the life cycle stages associated with the production and conversion of 1 ton $_{\mathrm{DM}}$ of ryegrass from cradle to the refinery gate. Results are presented for all ICs.

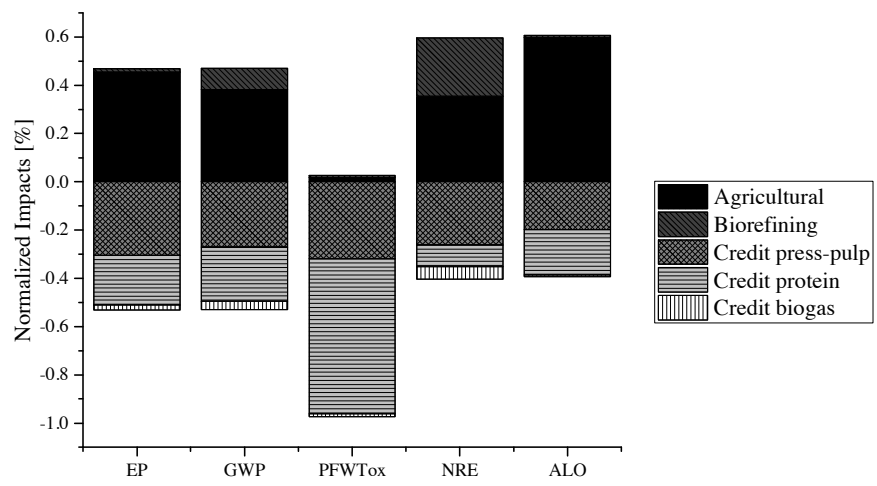

Figure 8. Hotspot analysis for the GBR using ryegrass as input biomass. The figure shows the impact related to the process and those avoided by the by-product.

For the induced impacts, the agricultural stage exhibits the largest contribution in almost all ICs, ranging from $94 \%$ and $99 \%$ for EP and ALO to $60 \%$ for NRE. The biorefinery has the highest contribution in the energy related ICs with $40 \%$ for NRE and $19 \%$ for GWP. Regarding the avoided impacts, they have a similar magnitude as the induced impact. The highest contribution is found for PFWTox. However, these results are artefact due to the different modelling approach as explained in section 3.1.3. From the results it is visible that the GBR has direct contribution only to energy related ICs (GWP, NRE). In the other ICs, the GBR instead has an indirect effect: the biorefining stage influences the conversion efficiency and hence the credits due to the GBR products that counterbalance the induced impacts of the agricultural stage. Figure 9 illustrates the impact associated with the GBR system. Results are presented for NRE, since it is the IC where the GBR has the highest impact. NRE can also be used as a good proxy for GWP since both ICs are connected with energy related processes (Laurent et al., 2012). The figure presents only the ryegrass scenario; a similar trend was however found for the other studied crops.

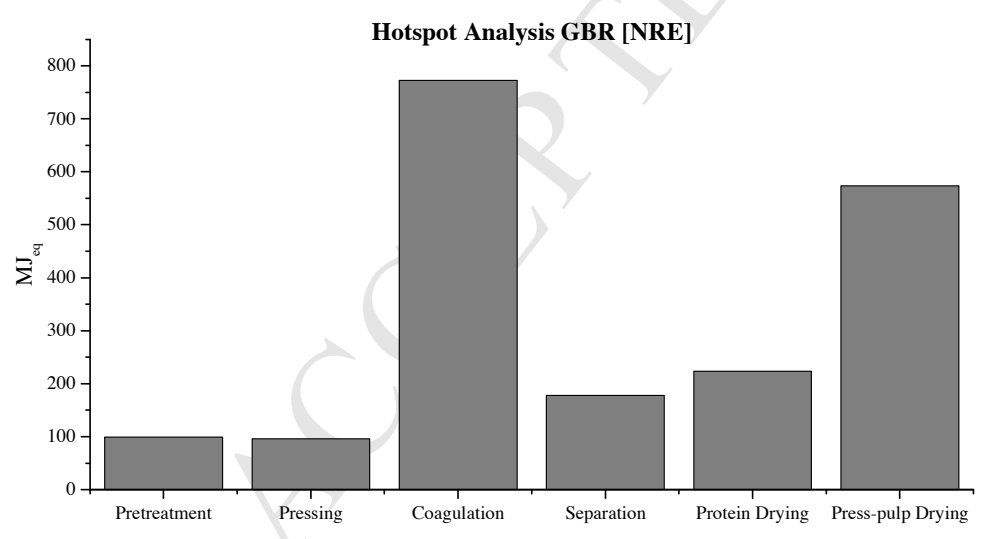

Figure 9. Hotspot analysis of the GBR for the conversion of 1tonDM of ryegrass as input biomass. The impact category chosen for the analysis is NRE. In the figure, the impact related to biorefining stage are shown.

The main contributing process for NRE is coagulation followed by the drying process for the press-pulp and the protein. The coagulation process accounts for $40 \%$ of the NRE impacts connected with the biorefinery section. Cake drying accounts for $30 \%$, while drying of the protein accounts for $11 \%$ of the NRE impacts of the GBR. The other processes have a lower contribution to the total NRE score. The high contribution of the coagulation process is due to the energy needed to heat up the juice to $80 \mathrm{C}$. For the drying process, the cake drying has three times higher contribution than the protein drying. Based on Table 6 it is possible to observe that this difference is mainly correlated with the different 
amounts of water in the final product, since DM before drying is similar (36.3\% for the protein, $35.7 \%$ for the cake) and DM after drying is the same at $95 \%$.

Two strategies can be used in order to reduce the impacts related to the heat consumptions in the biorefinery section: heat optimization and choice of heat source. The sensitivity analysis (see paragraph 3.3) evaluates the variation of the environmental impact potentials due to heat optimization. The scenario analysis (see paragraph 3.4 ) on the other hand evaluates the variation caused by different heat sources.

\subsection{Sensitivity Analysis}

Figure 10 presents the results of the sensitivity analysis. The results for each parameter are expressed as Sensitivity Ratios (SR). Depending on the IC, the tested parameters exhibit different sensitivities on the total impact potentials. The parameters included focus on the GBR process and only for the ryegrass scenario because sensitivities for the GBR processing of all feedstocks are assumed to be similar. For GWP the parameters connected with the quality of the GBR products and the conversion efficiency have the strongest effect. Cake substitution factor (SF_cake) has the highest SR, followed by efficiency of the protein separation in the centrifuge (\%prot_sep), protein extraction in the screw press (\%prot_to_juice) and the protein substitution factor (SF_protein). For GWP, efficiency related to heat consumption has a weaker influence on the results while efficiency related to electricity consumption has negligible effects. Regarding NRE SF_cake again exhibit the highest SR followed by SF_protein, \%prot_sep and heat_coag having comparable SR scores. The efficiency of protein extraction in the screw press, biogas production and heat for drying are less important for NRE results. Efficiency related to electricity consumption has negligible effect on the impact potential. From the results presented in figure 10 it is visible that the model is most sensitive to the quality of the GBR products, followed by the efficiency in protein separation. Regarding heat efficiency the model is more sensitive (i.e. the SR score is higher) for NRE than for GWP impacts. Lastly, electricity efficiency has a negligible effect on the total score for both ICs. By observing the parameters controlling the quality of the GBR products (the last 3 parameters in Figure 10), the quality of the press-pulp (in terms of feed quality) is more relevant than the protein quality; while biogas production has a minor effect compared to the previous two. The reason is the different amounts of GBR product: $70 \%$ of the feedstock $\mathrm{DM}$ is converted to the solid fraction while $17 \%$ goes to the protein concentrate. However, the SR is not linearly proportional to the mass, suggesting that the credits caused by the replacement of soybean meal might have higher effects than those from the cake. Furthermore, the parameters affecting the feed quality exhibit larger influence on GWP than on NRE. The reason behind is that for GWP the quality not only affects how much conventional product is replaced, it also increases the avoided ILUC. Regarding the processing condition parameters, it is observed that improving the conversion efficiencies (i.e. how much protein from the feedstock ends up in the protein concentrate) has larger influence on GWP than improving the energy consumption while for NRE conversion efficiencies have a similar effect.

Among the conversion efficiencies, the parameter representing the protein separation in the centrifugation step (\%prot_sep) has larger influence than the one representing protein extraction during screw-pressing. If a higher separation efficiency is achieved in the screw-press, the nutritional properties of the press-pulp decrease which counteracts the positive effect of a higher productivity of protein-feed. If the protein separation efficiency increases, during the centrifugation step, the effects on biogas production are limited. For heat consumption, the efficiency of the coagulation step has more influence than the efficiency of the drying process. The drying process recycles part of the heat to be used in the coagulation process. Hence, the improvement on heat consumption of this process will have a limited effect compared to improving it in the coagulation step. 

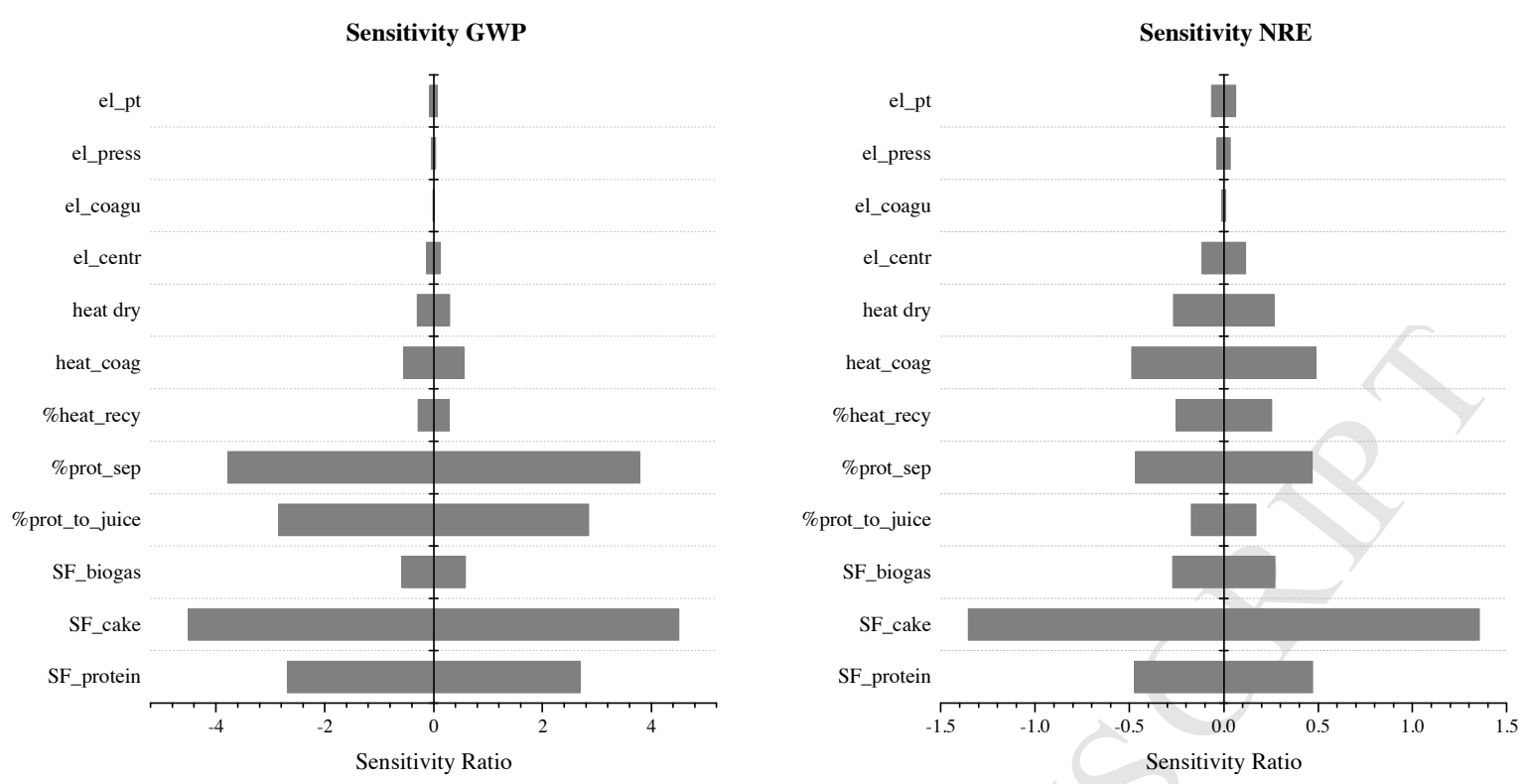

Figure 10. Results of the sensitivity analysis for GWP and NRE for the ryegrass biomass processing. Each parameter presented in Table 7 was varied $+1-10 \%$ and the effect on the assessment results quantified. The results are presented as SRs (see eq.1).

\subsection{Scenario Analysis}

Figure 11 presents the results of the scenario analyses. Four alternative scenarios are built to discuss the effect of changes in electricity supply or heat source. Based on the results, it can be concluded that the future electricity mix forecast for Denmark (with lower fossil fuel dependence) will not have a strong effect on the GBR impacts. With the forecast 2035 energy mix the GBR impacts are reduced by 5\%-6\% and with the 2050 electricity mix the reduction amounts to $10-12 \%$ depending on the IC. Alternative heat sources on the other hand have large effects on the environmental performance of the GBR, as pointed out also in the sensitivity analysis. Using biogas as fuel to supply heat to the GBR can reduce the impacts by $68-69 \%$ while by using woodchips the reduction is even larger: $74-78 \%$ of the baseline impacts.

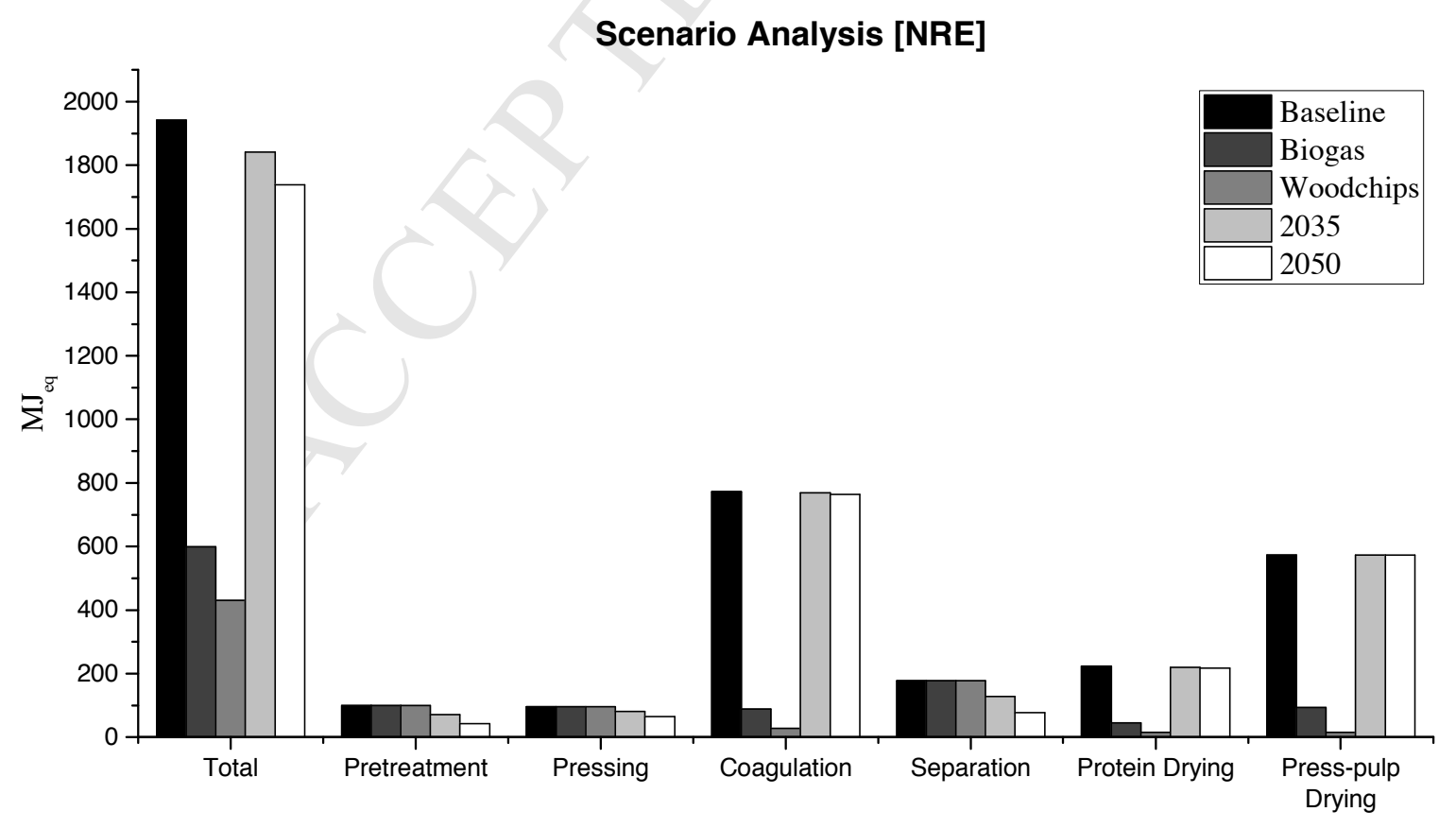


Figure 11. Scenario analysis testing alternative heat and electricity sources against the reference for the ryegrass biomass processing. The scenarios are presented in Table 8.

\section{Conclusion and perspectives}

This study addresses the suitability of different feedstocks for GBR conversions, by applying LCA at the early design stage of the biorefinery. Additionally, our study identifies potential improvements for further reduction of the environmental burdens through optimization of the biorefinery. Four different crops have been assessed: grass-clover, ryegrass, alfalfa and festulolium. For each crop, a detailed process flowsheet of the GBR system was developed to estimate the respective product yields and qualities together with consumption of utilities and auxiliary materials. Lastly, we performed a sensitivity and scenario analysis to provide recommendation for the technology developers on the focus points in the biorefinery to reduce the environmental impacts further.

The results show alfalfa as the most suitable crop, due to its high yield and low fertilization rates. This crop has the best performance across all ICs, except for ALO. For this impact category, festulolium appears to perform best because it has the highest yield among the studied crops. However, the higher yield is obtained through high fertilization rates and other agricultural inputs, which increase the contributions to other ICs such as NRE. As, highlighted in the introduction, the results on the environmental screening of selecting different types of the green biomasses was thus important tool to help in the decision-making process, e.g., to judiciously select the biomasses for an industrial production of feed protein in a large scale GBR system. Since, the farm inputs and management practices, e.g. agro-chemicals applied, and the land use were different in the selected biomasses, the corresponding environmental impacts were also varying. These revealed that a holistic evaluation of different grassland biomasses was important in a decision-making process, e.g., introducing specific green biomass in a crop rotation system and then prioritizing them for the conversion in a large scale GBR system. Based on the current study, major influential crop-based parameters were the: (i) farm inputs and the corresponding yields, (ii) crude protein and fiber contents in the biomass, and (iii) conversion efficiency to produce the potential biobased products. These collectively were important to produce biobased products with a lower environmental impact, The agricultural stage plays a major role in most of the ICs assessed, while the GBR has a relevant direct contribution only in the mainly energy-related ICs such as GWP and NRE. Within the GBR system, the majority of the impacts arise from the coagulation and drying processes due to their high energy demands. These processes could be improved by system optimization (e.g. heat recycling) or by using alternative heat sources with lower environmental impacts (e.g. woodchips) as shown in the sensitivity and scenario analysis. Alternatively, if the protein feed is used on-site in wet feeding systems, drying could be avoided. For the press-pulp, alternative utilization such as silage or as a feedstock for fermentation processes could reduce the drying needs.

Optimization of the GBR system should also focus on improving the overall conversion efficiency, as demonstrated by our sensitivity analysis. An improved conversion efficiency will result in a lower consumption of biomass per produced unit, hence reducing the contribution of the agricultural stage (dominating stage of the induced impacts) to the environmental impacts of the GBR products. However, if improved protein separation efficiency is achieved at the pressing stage, the utilization options of the solid fraction as a feed will be limited. Hence, alternative utilization options should be identified (e.g. feedstock for biological conversion, utilization as structural material etc.). Regarding the avoided impacts, it has been shown that the protein feed and the energy-feed play major roles in reducing the environmental impacts. This is an important point seen in the light of the recent trends in biomass conversion that focuses in enlarging the product portfolio by exploiting all the biomass components; instead of maximizing the production of one single product. Furthermore, it presents a clear justification for implementing such biorefinery technologies in grass drying plants were only an energy-rich feed is produced.

Procurement of fresh biomass for the GBR can pose challenges to the transportation logistics, which are not considered in this study. However, a small-scale decentralized scenario, allows for reducing the logistic challenges associated with delivering fresh biomass; but on the other side the technology involved doesn't allow for extraction of high value products and to achieve high efficiencies, due to the small scale of the plant. An important limitation to the taken LCA approach is our use of pilot scale data to project impacts of a hypothetical (full industrial scale) biorefinery. However, since the scale of the hypothetical full scale biorefinery is assumed to be small, pilot scale data are assumed to provide a reasonable representativeness of the relevant processes. Furthermore, the aim of our study is to compare the performance of different crops suitable for biorefinery conversion, and it seems fair to assume that the scaling error introduced by the use of pilot scale data will be similar for all biomasses and hence not bias the comparison. Another possible limitation is the choice of substitution factor used to quantify the products that are avoided by the different outputs from the refinery. The study adopted the same methodology as used in the Ecoinvent database, however if 
alternative properties are used to determine the substitution factor, results could be affected, especially considering the previously mentioned strong influence of some of the avoided impacts.

\section{Acknowledgements}

This work was supported by the Bio-Value platform (biovalue.dk) under the SPIR initiative by The Danish Council for Strategic Research and The Danish Council for Technology and Innovation and Innovation Fund Denmark.

Uffe Jørgensen and Kiril Manevski from the Department of Agroecology, Aarhus Univeristy for the initial discussion and feedbacks regarding the farm input for the production of festulolium.

\section{Appendix A}

Supplementary data related to this article can be found in Appendix A.

\section{$7 \quad$ Reference List}

Ahlgren, S., Björklund, A., Ekman, A., Karlsson, H., Berlin, J., Börjesson, P., Ekvall, T., Finnveden, G., Janssen, M., Strid, I., 2013. LCA of biorefineries identification of key issues and methodological recommendations. doi:f3 2013:25

Andersen, M., Kiel, P., 2000. Integrated utilisation of green biomass in the green biorefinery. Ind. Crops Prod. 11, 129137. doi:10.1016/S0926-6690(99)00055-2

Bals, B.D., Dale, B.E., Balan, V., 2012. Recovery of Leaf Protein for Animal Feed and High-Value Uses.

Brandão, M., Milà i Canals, L., Clift, R., 2011. Soil organic carbon changes in the cultivation of energy crops: Implications for GHG balances and soil quality for use in LCA. Biomass and Bioenergy 35, 2323-2336. doi:10.1016/j.biombioe.2009.10.019

Buswell, A.M., Mueller, H.F., 1952. Mechanism of Methane Formation. Ind. Eng. Chem. 44, 550-552. doi:10.1021/ie50507a033

Cherubini, F., 2010. The biorefinery concept: Using biomass instead of oil for producing energy and chemicals. Energy Convers. Manag. 51, 1412-1421. doi:10.1016/j.enconman.2010.01.015

Cherubini, F., Jungmeier, G., 2009. LCA of a biorefinery concept producing bioethanol, bioenergy, and chemicals from switchgrass. Int. J. Life Cycle Assess. 15, 53-66. doi:10.1007/s11367-009-0124-2

Cherubini, F., Jungmeier, G., Wellisch, M., Willke, T., Skiadas, I., Van Ree, R., de Jong, E., Ree, R. Van, de Jong, E., 2009. Toward a common classification approach for biorefinery systems. Biofuels, Bioprod. Biorefining 3, 534546. doi:10.1002/bbb

Cherubini, F., Strømman, A.H., Ulgiati, S., 2011. Influence of allocation methods on the environmental performance of biorefinery products - A case study. Resour. Conserv. Recycl. 55, 1070-1077. doi:10.1016/j.resconrec.2011.06.001

Cherubini, F., Ulgiati, S., 2010. Crop residues as raw materials for biorefinery systems - A LCA case study. Appl. Energy 87,47-57. doi:10.1016/j.apenergy.2009.08.024

Cong, R.G., Termansen, M., 2016. A bio-economic analysis of a sustainable agricultural transition using green biorefinery. Sci. Total Environ. 571, 153-163. doi:10.1016/j.scitotenv.2016.07.137

Dalgaard, T., Halberg, N., Porter, J.R., 2001. A model for fossil energy use in Danish agriculture used to compare organic and conventional farming. Ecosyst. Environ. 87, 51-65.

DCA, 2016. Biobased green protein. Danish Centre For Food and Agriculture, Aarhus University, Aarhus, Denmark. 
Dijkman, T.J., Birkved, M., Hauschild, M.Z., 2012. PestLCI 2 . 0 : a second generation model for estimating emissions of pesticides from arable land in LCA. Int. J. Life Cycle Assess. 973-986. doi:10.1007/s11367-012-0439-2

EEA, 2013. EMEP/EEA air pollutant emission inventory guidebook 2013: Technical guidance to prepare national emission inventories. EEA Tech. Rep. 23. doi:10.2800/92722

Environdec, 2015. The EPD method [WWW Document]. URL http://www.environdec.com/sv/

Esen, M., Yuksel, T., 2013. Experimental evaluation of using various renewable energy sources for heating a greenhouse. Energy Build. 65, 340-351. doi:10.1016/j.enbuild.2013.06.018

Fantke, P., Bijster, M., Guignard, C., Hauschild, M., Huijbregts, M., Jolliet, O., Kounina, A., Magaud, V., Margni, M., McKone, T.E., Posthuma, L., Rosenbaum, R.K., van der Meent, D., van Zelm, R., 2015. USEtox(R) 2.0 Documentation (Version 1). doi:10.11581

Fiorentino, G., Ripa, M., 2016. Chemicals from biomass: technological versus environmental feasibility. A review. Biofuels, Bioprod. Biorefining. doi:10.1002/bbb.1673

Hamelin, L., Naroznova, I., Wenzel, H., 2014. Environmental consequences of different carbon alternatives for increased manure-based biogas. Appl. Energy 114, 774-782. doi:10.1016/j.apenergy.2013.09.033

Hermansen, J.E., Jørgensen, U., Lærke, P.E., Manevski, K., Jensen, S.K., Weisbjerg, M.R., Dalsgaard, T.K., Asp, T., Amby-jensen, M., Aage, C., Sørensen, G., Jensen, V., Gylling, M., Lindedam, J., Lübeck, M., Erik, O.G., 2017. Green Biomass: protein production through bio-refining green biomass. DCA - Danish Centre for Food and Agriculture. Aarhus, Denmark.

Hjorth, M., Gränitz, K., Adamsen, A.P.S., Møller, H.B., 2011. Extrusion as a pretreatment to increase biogas production. Bioresour. Technol. 102, 4989-4994. doi:10.1016/j.biortech.2010.11.128

Hsu, D.D., Inman, D., Heath, G.A., Wolfrum, E.J., Mann, M.K., Aden, A., 2010. Life cycle environmental impacts of selected U.S. ethanol production and use pathways in 2022. Environ. Sci. Technol. 44, 5289-97. doi:10.1021/es100186h

Huijbregts, M.A.J., Steinmann, Z.J.N., Elshout, P.M.F., Stam, G., Verones, F., Vieira, M., Zelm, R. Van, 2015. ReCiPe 2015: a Life Cycle Impact Assessment Method at Midpoint and Endpoint Level Report I: Characterisation Factors. Department of Environmental Science, Radboud University Nijmegen.

IPCC, 2006. 2006 IPCC Guidelines for National Greenhouse Gas Inventories Volume 4 Agriculture, Forestry and Other Land Use, 2006 IPCC Guidelines for National Greenhouse Gas Inventories Volume 4 Agriculture, Forestry and Other Land Use.

Jørgensen, K., Hummelmose, A.B., Pedersen, B.K., Wøyen, T.T., Mægaard, E.ruun, L.K., 2011. Budgetkalkuler 2010 pr. oktober 2010. SEGES, Aarhus, Denmark.

JRC, 2011. Recommendations for Life Cycle Impact Assessment in the European context - based on existing environmental impact assessment models and factors. ILCD Handb. Int. Ref. Life Cycle Data Syst. doi: $10.278 / 33030$

Kamm, B., 2013. Introduction of Biomass and Biorefineries, in: Xie, H., Gathergood, N. (Eds.), The Role of Green Chemistry in Biomass Processing and Conversion. John Wiley \& Sons, Inc., pp. 1-26.

Kamm, B., Hille, C., Schönicke, P., Dautzenberg, G., 2010. Green biorefi nery demonstration plant in Havelland (Germany). Biofuels, Bioprod. Biorefining 253-262. doi:10.1002/bbb.218

Kamm, B., Kamm, M., 2007. International biorefinery systems. Pure Appl. Chem. 79, 1983-1997. doi:10.1351/pac200779111983

Kamm, B., Kamm, M., Gruber, P.R., Kromus, S., 2006. Biorefinery Systems: An Overview, in: Biorefineries Industrial Processes and Products. Elsevier Inc., pp. 1-40. doi:10.1016/B978-0-444-59561-4.00014-0 
Kamm, B., Schönicke, P., Hille, C., 2016. Green biorefinery - Industrial implementation. Food Chem. 197, 1341-1345. doi:10.1016/j.foodchem.2015.11.088

Kamm, B., Schönicke, P., Kamm, M., 2009. Biorefining of Green Biomass - Technical and Energetic Considerations. CLEAN - Soil, Air, Water 37, 27-30. doi:10.1002/clen.200800122

Kragbæk, D.J.V., 2014. Protein Yields and Amino Acid Characterization of Juice and Pulp from White Clover , Red Clover, Lucerne and Ryegrass. Aarhus Univeristy, Aarhus, Denmark.

Kristensen, T., 2015. Beregning af grovfoderudbytte på kvægbrug ud fra regnskabdata. DCA - Nationalt Center for Fødevarer og Jordbrug, Aarhus, Denmark.

Kromus, S., Wachter, B., Koschuh, W., Mandl, M., Krotscheck, C., Narodoslawsky, M., 2004. The Green Biorefinery Austria - Development of an Integrated System for Green Biomass Utilization. Chem. Biochem. Eng. Q. 18, 712.

Laurent, A., Olsen, S.I., Hauschild, M.Z., 2012. Limitations of carbon footprint as indicator of environmental sustainability. Environ. Sci. Technol. 46, 4100-4108.

Leiß, S., Venus, J., Kamm, B., 2010. Fermentative production of L-lysine-L-lactate with fractionated press juices from the green biorefinery. Chem. Eng. Technol. 33, 2102-2105. doi:10.1002/ceat.201000314

Malça, J., Freire, F., 2010. Life-cycle studies of biodiesel in Europe: A review addressing the variability of results and modeling issues. Renew. Sustain. Energy Rev. 15, 338-351. doi:10.1016/j.rser.2010.09.013

Mandl, M.G., 2010. Status of green biorefining in Europe. Biofuels, Bioprod. Biorefining 4, $268-274$. doi: $10.1002 / b b b .219$

Manik, Y., Halog, A., 2012. A Meta-Analytic Review of Life Cycle Assessment and Flow Analyses Studies of Palm Oil Biodiesel. Integr. Environ. Assess. Manag. 9, 134-141. doi:10.1002/ieam.2012-024

Milà i Canals, L., Romanyà, J., Cowell, S.J., 2007. Method for assessing impacts on life support functions (LSF) related to the use of "fertile land" in Life Cycle Assessment (LCA). J. Clean. Prod. 15, 1426-1440. doi:10.1016/j.jclepro.2006.05.005

Molinuevo-Salces, B., Santamaria, M., Kiel, P., Uellendahl, H., Lubek, M., 2015. ORGANOFINERY: From organic green crops to protein, energy and fertilizer, in: 11th International Conference on Renewable Resources \& Biorefineries. York.

Møller, J., Thøgersen, R., Helleshøj, M., 2005. Fodermiddeltabel, Rapport nr.112. DCA - Nationalt Center for Fødevarer og Jordbrug, Aarhus, Denmark.

NaturErhvervstyrelsen, 2015. Vejledning om gødsknings-og harmoniregler. Ministeriet for Fødevarer, Landbrug og Fiskeri. Copenhagen, Denmark.

NaturErhvervstyrelsen, 2013. Vejledning om gødskings-og harmoniregler. Ministeriet for Fødevarer, Landbrug og Fiskeri. Copenhagen, Denmark.

Nemecek, T., Kägi, T., 2007. Life Cycle Inventories of Agricultural Production Systems. Zurich and Dubendorf.

Nielsen, P.H., Wenzel, H., 2007. Environmental Assessment of Ronozyme ${ }^{\circledR}$ P5000 CT Phytase as an Alternative to Inorganic Phosphate Supplementation to Pig Feed Used in Intensive Pig Production. Int J LCA 12, $12-514$. doi: $10.1065 /$ lca2006.08.265.2

O’Keeffe, S., Schulte, R.P.O., Lalor, S.T.J., O’Kiely, P., Struik, P.C., 2011a. Green biorefinery (GBR) scenarios for a two-cut silage system: Investigating the impacts of sward botanical composition, $\mathrm{N}$ fertilisation rate and biomass availability on GBR profitability and price offered to farmers. Biomass and Bioenergy 35, 4699-4711. doi:10.1016/j.biombioe.2011.06.051

O’Keeffe, S., Schulte, R.P.O., Sanders, J.P.M., Struik, P.C., 2012. II. Economic assessment for first generation green 
biorefinery (GBR): Scenarios for an Irish GBR blueprint. Biomass and Bioenergy 41, 1-13. doi:10.1016/j.biombioe.2011.11.018

O'Keeffe, S., Schulte, R.P.O., Sanders, J.P.M., Struik, P.C., 2011b. I. Technical assessment for first generation green biorefinery (GBR) using mass and energy balances: Scenarios for an Irish GBR blueprint. Biomass and Bioenergy 35, 4712-4723. doi:10.1016/j.biombioe.2011.06.017

Ørum, J.E., 2013. Bekaempelsesmiddel- statistik 2013. Copenhagen, Denmark.

Parajuli, R., Dalgaard, T., Birkved, M., 2018. Can farmers mitigate environmental impacts through combined production of food, fuel and feed? A consequential life cycle assessment of integrated mixed crop-livestock system with a green biorefinery. Sci. Total Environ. 619-620, 127-143. doi:10.1016/j.scitotenv.2017.11.082

Parajuli, R., Dalgaard, T., Jørgensen, U., Peter, A., Adamsen, S., Knudsen, M.T., Birkved, M., Gylling, M., Schjørring, J.K., 2015. Biorefining in the prevailing energy and materials crisis: a review of sustainable pathways for biorefinery value chains and sustainability assessment methodologies. Renew. Sustain. Energy Rev. 43, 244-263. doi:10.1016/j.rser.2014.11.041

Parajuli, R., Knudsen, M.T., Birkved, M., Djomo, S.N., Corona, A., Dalgaard, T., 2017a. Environmental impacts of producing bioethanol and biobased lactic acid from standalone and integrated biorefineries using a consequential and an attributional life cycle assessment approach. Sci. Total Environ. 598, 497-512. doi:10.1016/j.scitotenv.2017.04.087

Parajuli, R., Knudsen, M.T., Djomo, S.N., Corona, A., Birkved, M., Dalgaard, T., 2017b. Environmental life cycle assessment of producing willow, alfalfa and straw from spring barley as feedstocks for bioenergy or biorefinery systems. Sci. Total Environ. 586, 226-240. doi:10.1016/j.scitotenv.2017.01.207

Parajuli, R., Kristensen, I.S., Knudsen, M.T., Mogensen, L., Corona, A., Birkved, M., Peña, N., Graversgaard, M., Dalgaard, T., 2016. Environmental life cycle assessments of producing maize, grass-clover, ryegrass and winter wheat straw for biorefinery. J. Clean. Prod. 142, 1-13. doi:10.1016/j.jclepro.2016.10.076

PE International AG, 2012. GaBi Manual 388.

Petersen, B.M., Knudsen, M.T., Hermansen, J.E., Halberg, N., 2013. An approach to include soil carbon changes in life cycle assessments. J. Clean. Prod. 52, 217-224. doi:10.1016/j.jclepro.2013.03.007

Ree, R. van, Jong, E. de, Bell, G., Schuck, S., Jungmeier, G., Wellisch, M., Felby, C., Jorgensen, H., Stichnothe, H., Clancy, M., Bari, I. de, Kimura, S., Annevelink, B., Kwant, K., Torr, K., Spaeth, J., 2014. IEA Bioenergy, Task 42 Biorefining: Sustainable and synergetic processing of biomass into marketable food \& feed ingredients, products (chemicals, materials) and energy (fuels, power, heat). doi:10.1016/S0961-9534(07)00064-5

Richter, F., Fricke, T., Wachendorf, M., 2010. Utilization of semi-natural grassland through integrated generation of solid fuel and biogas from biomass. III. Effects of hydrothermal conditioning and mechanical dehydration on solid fuel properties and on energy and greenhouse gas balances. Grass Forage Sci. 65, 185-199. doi:10.1111/j.1365-2494.2010.00737.x

Santamaría, M., Lübeck, M., Uellendahl, H., 2015. Combining protein extraction and anaerobic digestion to produce feed, fuel and fertilizer from green biomass - An organic biorefinery concept, in: 11th International Conference on Renewable Resources \& Biorefineries. York.

Schmidt, J.H., Weidema, B.P., Brandão, M., 2015. A framework for modelling indirect land use changes in Life Cycle Assessment. J. Clean. Prod. 99, 230-238. doi:10.1016/j.jclepro.2015.03.013

SEGES, 2010. Growing instructions-Crops. Agro Food Park Aarhus, Denmark.

Sohn, J.L., Kalbar, P.P., Banta, G.T., Birkved, M., 2017. Life-cycle based dynamic assessment of mineral wool insulation in a Danish residential building application. J. Clean. Prod. 142, 3243-3253. doi:10.1016/j.jclepro.2016.10.145

Sommer, S.G., Schjoerring, J.K., Denmead, O.T., 2004. Ammonia Emission from Mineral Fertilizers and Fertilized 
Crops. Adv. Agron. 82, 557-622. doi:10.1016/S0065-2113(03)82008-4

Termansen, M., Gylling, M., Jørgensen, U., Hermansen, J., Han-, L.B., Knudsen, M.T., Adamsen, A.P.S., Ambyejensen, M., Jensen, V., Jensen, S.K., Andersen, H.E., Gyldenkærne, S., 2016. Green biomass. DCA - Danish Centre for Food and Agriculture, Aarhus, Denmark.

Thøgersen, R., Kjeldsen, A.M., 2015. Grovfoder 2015. SEGES, Aarhus, Denmark.

Thomsen, M.H., Bech, D., Kiel, P., 2004. Manufacturing of stabilised brown juice for L-lysine production - from university lab scale over pilot scale to industrial production. Chem. Biochem. Eng. Q. 18, 37-46.

Vinther, F.P., 2005. SimDen - A simple empirical model for quantification of N $2 \mathrm{O}$ emission and denitrification.

Weidema, B.P., Bauer, C., Hischier, R., Mutel, C., Nemecek, T., Reinhard, J., Vadenbo, C.O., Wernet, G., 2013. Data quality guideline for the ecoinvent database version 3 .

Wernet, G., Bauer, C., Steubing, B., Reinhard, J., Moreno-Ruiz, E., Weidema, B., 2016. The ecoinvent database version 3 (part I): overview and methodology. Int. J. Life Cycle Assess. 21, 1218-1230. doi:10.1007/s11367-016-1087-8

Wiloso, E.I., Heijungs, R., De Snoo, G.R., 2012. LCA of second generation bioethanol: A review and some issues to be resolved for good LCA practice. Renew. Sustain. Energy Rev. 16, 5295-5308. doi:10.1016/j.rser.2012.04.035

Xiu, S., Shahbazi, A., 2015. Development of Green Biorefinery for Biomass Utilization: A Review. Trends Renew. Energy 1,4-15. doi:10.17737/tre.2015.1.1.008 


\section{Highlights}

- The environmental profiles of possible feedstocks for green biorefinery is studied

- Alfalfa provides the best overall environmental performance for most of the ICs

- Festulolium has the best performance on Agricultural land occupation impacts

- Drying and coagulation carries the highest impacts in the biorefining stage 